\title{
13-18 Yaş Grubu Ergenlerdeki Ego Durumları ile Anne Babalarının Bilgi Düzeyleri ve Anne Baba Tutumlarının İlişkisi
}

\author{
DOI: 10.26466/opus.594514 \\ * \\ Seden Durmuş Çalışkan - Halis Özerk* \\ *Uzm. Psk., Arel Üniversitesi Sefaköy/İstanbul/Türkiye \\ E-Posta: sdndrms@hotmail.com \\ ORCID: 0000-0001-5848-8924 \\ *Dr. Öğr. Üyesi, Arel Üniversitesi Sosyal Bilimler Enstitüsü/Sefaköy/İstanbul/Türkiye \\ E-Posta: halisozerk@halisozerk.com \\ ORCID: 0000-0001-5530-6638
}

\section{Öz}

Bu çalışmada, 13-18 yaş grubu ergenlerin ego durumlarının, anne babalarının anne babalık bilgi düzeyleri ve çocuk yetiştirmeye ilişkin tutumları ile ilişkisini ortaya koymak amaçlanmıştır. Bununla beraber bu ilişki durumunu katılımclların yaş, cinsiyet, eğitim düzeyi ve sosyo-ekonomik düzey gibi çeşitli demografik değ̈işkenleri bakımından incelemek de amaçlanmıştır. Çalışmasının evrenini, Düzce ili ile Akçakoca, Cumayeri ve Çilimli ilçelerinde bulunan ortaöğretim düzeyinde öğrenim gören 13-18 yaş grubu ergenler ve bu ergenlerin aileleri oluşturmaktadır. Örneklem ise 130 anne baba ve 130, 13-18 yaş grubu ergen olmak üzere 260 kişiden oluşmaktadır. Örnekleme yöntemi kümeleme oransız random örneklemedir ve ilişkisel tarama modelindedir. Araştırmaya katılan 13-18 yaş grubu 130 ergene kendilerinde algiladıkları özelliklerin işaretlenmesi istenerek, Transaksiyonel Analiz Kuramı bă̆lamında Ego Durumları Ölçeği (EDÖ) uygulanmıştır. Bu kişilerin ebeveynlerinden oluşan 130 kişiye de veri toplama araçlar olarak geçerlik ve güvenirliğe sahip olan Anne Babalık Bilgi Testi (ABBT) ve Aile Hayatı Çocuk Yetiştirme Tutum Ölçeği (PARI, Parental Attitude Research) uygulanmıştır. Ayrıca araştırmacı tarafindan geliştirilmiş olan Demografik Bilgi Formu verilerek doldurulması sağlanmıştır. Tüm verilerin anlamlılık düzeyi $p<0.05$ düzeyinde sınanmıştır. Araştırmadan elde edilen sonuçlara bakıldığında, anne-babaların çocuk yetiştirmeye ilişkin tutumlarının ve anne babalık bigi düzeylerinin 13-18 yaş grubu ergenlerin kendilerinde algıladıkları ego durumuna göre anlamlı bir farklılaşma göstermediği bulunmuştur. Anne-babaların, çocuk yetiştirmeye ilişkin tutumları ve anne babalık bilgi düzeyleri arasında negatif yönlü anlamlı bir ilişki bulunmuştur. Anne babalarn çocuk yetiştirmeye ilişkin ana-babalık bilgi düzeylerinin kendi öğrenim durumlarına, çalı̧ıp çalışmadıklarına, sahip oldukları çocuk sayılarına göre anlamlı farklılık gösterdiği görü̈lmüştür. Ayrıca Anne babalık bilgi düzeyinin, ana babaların PARI puanlarını anlamlı derecede yordadı̆̆ bulunmuştur.

Anahtar Kelimeler: Tutum, Anne-Babalık Bilgi, Ego Durumları 


\title{
Relationship Between Ego States in Teenagers in 13-18 Age Group and Consciousness Levels of Parents with Parents' Attitude
}

\begin{abstract}
In this study, it is aimed to reveal the relationship of ego states of teenagers in the 13-18 age group with parentage consciousness levels of parents and their attitudes relating to child rearing. In addition, this paper also scrutinizes this relationship in terms of several demographical variables such as age, gender, educational background, and socio-economic level. The population consisted of teenagers in the 13-18 age group who study in secondary education in Akçakoca, Cumayeri and Çilimli districts of Düzce province; families of these teenagers were also included in the population. Sample of the study composed of 260 persons whose 130 were parents and other 130 were the teenagers in the related age group. The sampling method is the clustering irrational random sampling; it is in the form of relational screening model. Ego States Scale (ESS) within the scope of Transactional Analysis Theory was applied 130 teenagers in 13-18 age group by asking them for checking the boxes which summarize their characteristics. As data collection tools, 130 parents in the survey was applied Parentage Information Test and Parental Attitude Research (PARI) whose validity and reliability are approved. Moreover, the Demographic Information Form that was developed by the same investigator was filled by participants. The significance level of all the data was tested at $p<0.05$ level. It is pointed out when looking at research results that parentage consciousness level of parents and also parents' attitudes relating to child rearing do not differentiate by the self-perceived ego states of teenagers in the 13-18 age group. There is found a negative significant relationship between parents' attitudes relating to child rearing and parentage consciousness levels. There is also seen a significant difference between parentage information level of parents between their educational level, working status and number of children. In addition to all these, for research results, parents significantly predict PARI scores.
\end{abstract}

Keywords: Attitude, Parentage Consciousness Level, Ego States 


\section{Giriş}

Aile, Türk Dil Kurumu (TDK) tarafından "Evlilik ve kan bağına dayanan, karı, koca, çocuklar, kardeşler arasındaki ilişkilerin oluşturduğu toplum içindeki en küçük birlik" olarak tanımlanmaktadır (TDK, 2017). Baumrind (1971) ve Rohner, Khaleque ve Cournnoyer (2007), ailelerin yapılarının ve ebeveynlerin çocuk yetiştirmeye ilişkin tutumlarının, çocukların kişilik gelişimlerini, davranışlarının sağlıklılık bakımından olumlu ya da olumsuz olup olmayacağını belirleyebildiğine dikkatleri çekmektedirler.

Horney'e göre; çocuğun sağlıklı bir kişilik ve davranış geliştirebilmesinin koşulu, ailede koşulsuz sevgi, yerinde destek ve doğal bir anlayış ortamının bulunmasıdır. Çocuk, böyle bir aile ortamında gelişimsel dönemlerini sağlıklı bir şekilde geçirerek kendini geliştirebilir (Geçtan, 1992, s.167). Bu anlamda, bireyin temel davranış, örüntülerinin ve kişilik özelliklerinin ağırlıklı olarak aile ortamında oluştuğu kabul edilmektedir (Özerk, 2006, s.4).

Yörükoglu (1993, s.169), çocuk yetiştirmede amacın, sağlıklı bir kişilik oluşturmak olduğunu, kişiliğin temellerinin de ilk beş, altı yıl içinde atıldığını, dolayısıyla bu kişiliğin dengeli ve uyumlu olabilmesinin gelişim basamaklarının örselenmeden aşılmasına bağlı olduğunu bunun için de ana baba tutumlarının çok önemli olduğunu belirtmektedir.

Özerk (2006, s.116-117), yaptığı çalışmada, anne babaların çocuk yetiştirme sürecindeki tutumlarının en fazla magazinsel bilgiye en az da bilimsel bilgiye dayandığını göstermiştir. İlintili olarak anne babalık bilgi düzeyinin ise öğrenim düzeyi, sosyoekonomik düzey ve cinsiyete göre farklılık gözetmeksizin ortanın altında (düşük düzey) olduğunu bulgulamıştır. Dolayısıyla anne ve babaların çocuklarının yaşamalarını kendi disiplin yöntemleri ile yönlendirmeye çalışmaları, çocuğun sosyal yaşamında uyumlu ya da uyum güçlügü çeken bireyler haline gelmelerine sebep olabilmektedir.

Araştırmada ele alınan ergenlerin ego durumları ise; Berne' e göre ağırlıklı olarak doğumdan itibaren aile ortamındaki etkileşim biçimlerine bağlı olarak oluşmaya başlamakta ve 12 yaşında oluşumunu tamamlamaktadır (Akkoyun, 1995, s.10). (Mümkünse direkt olarak Berne'nin yazdıklarından alınsa daha iyi olur) 
Yapılan literatür taramalarında gerek anne baba tutumlarının gerek anne baba bilgi düzeylerinin ergenlerdeki ego durumlarıyla ilişkini ele alan herhangi bir çalışmaya (ulusal ve uluslararası yayımlarda) rastlanmamıştır. Dolayısıyla çalışma alan yazında bu boşluğu doldurabilmek amacıyla planlanmış ve gerçekleştirilmiştir.

\section{Kuramsal Çerçeve}

\section{Transaksiyonel Analiz (TA)}

Uluslararası Transaksiyonel Analiz Kuruluşu TA' nın tanımını şu şekilde yapmaktadır: "Transaksiyonel Analiz, kişisel olarak gelişmeyi ve değişmeyi sağlamak üzere kullanılan sistematik bir psikoterapi ve kişilik kuramıdır" (Stewart ve Joines, 2012; Çev. Akkoyun, 2017, s.37).

Kuramın kurucusu E. Berne(1961a), “íki kişinin ego durumları arasında gerçekleşen, ego durumlarının herhangi birinden gelen mesaja diğer kişinin ego durumlarının herhangi birinden gönderdiği tepkiye yani bir uyarıcı ve bir tepkiden oluşan bu iletişim birimine Transaksiyon adını vermektedir.

\section{Ego Durumları}

Transaksiyonel Analiz' in en temel kavramı olan ego durumları Berne tarafından "Bir ego durumu tutarlı bir davranışörüntüsüyle doğrudan ilişkili olarak, bu davranışlarla tutarl duygu ve yaşantılar örüntüsünün bir bütünü" şeklinde tanımlanmıştır. Daha sonra tanımına "İlişkili olduğu davranış örüntülerini güdüleyen duygular sistemi" ifadesini eklemiştir (akt. Casler, 1994, s.54).

Ego durumları bir nesneye değil, bir yaşantıya verilen ismi ifade etmektedir. Geçmişte yaşanılan olayları ve kaydedilen bilgileri içermektedir (Harris, 2013, s.47). Ego durumları yapısal ve fonksiyonel olmak üzere iki ayrı modelle incelenmektedir. 


\section{Yapısal Analiz}

Bir ego durumundaki düşünce, duygu ve davranış örüntüsünü tanımlama ve diğer ego durumlarından ayırt etme işlemine yapısal analiz denilmektedir (Nelson-Jones, 1982). Diğer bir ifade ile, kişiliğin, ego durumları kavramlarıyla analiz edilme sürecine yapısal analiz adı verilmektedir (Stewart ve Joines,2012, Çev: Akkoyun, 2017, s.48). Yapisal analize göre her bireyin kişiliğinde Yetişkin (Y), Çocuk (Ç) ve Ebeveyn (E) olmak üzere üç ego durumu bulunmaktadır (Akkoyun, 2011, s.18).

Ebeveyn Ego Durumu: Bireyin yaşamında karşılaştığı anne baba ya da ebeveyn figürlerinin duygu düşünce ve davranış örüntüleridir (Akkoyun, 1995:11; Solomon, 2003). Kişiliğin ayrı bir boyutu olarak 6 yaşlarında gelişmeye başlamaktadır (Harris, 2013, s.48-49).

Yetişkin Ego Durumu: Burada ve şimdi tepkileri verirken ortaya çıkan duygu, düşünce ve davranışları içermektedir. Kişinin mantıklı ve sağduyulu yanıdır. Kişinin yaşamını sürdürebilmesi için gerekli bir olgudur. Gerçeği test etme ve problem çözme stratejileri burada depolanmaktadır (Akkoyun, 2011, s.20).

Ebeveyn ve Çocuk ego durumundan farklı olarak, şu andaki gerçeğe uygun olan, nesnel verileri işler, yaşamda karşılaşılan problemlerin çözümlerine yönelik yaşantılardan oluşmaktadır (Stewart ve Joines, 2012; Çev. Akkoyun, 2017, s.51).

Çocuk Ego Durumu: Bireyin çocukluğundan izler taşıyan ve kişiliğinin bir parçası olan tutum, davranış, duygu ve düşünce örüntüleridir (Akkoyun, 2011, s.16). Transaksiyonel Analiz kuramına göre herkes çocukluğundaki gibi hisseden, düşünen, eyleme geçen ve tepkide bulunan küçük çocuğunu içinde taşır (Nelson-Jones, 1982, s.32).

Sağlıklı ve dengeli bir kişilikte, üç ego-durumu da bulunmaktadır (Stewart ve Joines, 2012; Çev. Akkoyun, 2017, s.51). 


\section{Fonksiyonel Analiz}

Fonksiyonel analiz, bireylerin ego durumları malzemelerini hem içsel hem de başkalarıyla ilişkilerinde harekete geçirmeleriyle ilgilidir. Daha çok gözlenen davranışların sınıflandırılması ile ilişkidir. Fonksiyonel analizde kişilerin, iletişimlerinde ne yaptıklarıyla ilgilenilir (Berne, 1961b; Akkoyun, 2011, s.21).

Fonksiyonel analize göre ego durumları beş şekilde gözlenmektedir. Bunlar, Eleştirel Ebeveyn (EE), Koruyucu Ebeveyn (KE), Uygulu Çocuk (UÇ), Doğal Çocuk (DÇ) ve Yetişkin ego durumudur (Akkoyun, 2011, s. $17-18,22)$

Eleştirel Ebeveyn Ego Durumu: Eleştirel Ebeveyn inatçı, güçlü, aşırı koruyucu, ilkeli cezalandırıcı ve görev yükleyicidir. Bu bağlamda bu ego durumuna Kontrol Edici Ebeveyn de denmektedir (Akkoyun, 2011, s.22).

Koruyucu Ebeveyn Ego Durumu: Koruyucu Ebeveyn affedici, özen gösterici, destekleyici, cesaretlendirici, ilgili, şefkatli, aşırı koruyucu ve endişelidir. Bu ego durumuna aynı zamanda Doğal Ebeveyn adı da verilmekte$\operatorname{dir}$ (Solomon, 2003, s.15; Akkoyun, 2011; James ve Jongeward, 1993, s.167).

Yetişkin Ego Durumu: Yaş ile ilgili olmayıp, temelde kişinin diğer ego durumlarının ihtiyaçlarını karşılama fonksiyonunda bulunur. Davranışlarını 'şimdi ve burada' ya göre, gerçeklik ve olasılıkları da dikkate alarak gerçekleştirir. Kişinin gerek kendisinin diğer ego durumlarına gerekse başkalarının ego durumlarına karşı etkin işlevlerde bulunur (Akkoyun, 2011; 17-18,22; Özerk, Ada ve Özerk, 2018, s.782; Eyicil ve Özerk, 2016, s.121).

Kişiliğin akılcı yanıdır. Algıladığı verileri gerçekliğe karşı değerlendirir ve doğru olduğunu düşündükleri üzerine karar verir (Roberts, 1975, s.184).

Uygulu Çocuk Ego Durumu: Berne, bu ego durumunu şöyle tanımlar: "Uygulu Çocuk, sanki ebeveynleri onu dinliyormuş ya da gözlüyormuş gibi tepkide bulunur. Çalışkandır, uslu ve asidir ya da ebeveyn figürlerinin herhangi birini 
esas alarak davranışlar gösterir" (Akkoyun, 2011, s.17-18,22; Özerk, Ada ve Özerk, 2018, s.782; Eyicil ve Özerk, 2016, s.121).

Doğal Çocuk ego durumu: Kendi ihtiyaç, istek ve kurallarına göre davranmaktadır. Yapmak istediği şeyleri ne zaman isterse yapabilmek özgürlüğüne sahip olmak için çalışır. Spontane bir şekilde hareket ederek, sevgi, aşk, sohbet, yaratıcılık saldırganlık, kızgınlık ve başkaldırma gibi durumlarda doğal tepkilere sahiptir (Roberts, 1975).

Doğal Çocuk Ego durumu baskın olarak bulunan kişiler, taşkın, girişimci, kendini sınırlamada güçlük çeken, diğer insanları kendi hazları konusunda kullanan kişiler şeklinde tanımlanabilmektedir (Williams ve Best, 1982; akt. Aş1l1, 2001).

\section{Anne Babaların Çocuk Yetiştirme Tutumları}

Gelişim psikolojisinde çocuk yetiştirme tutumlarıyla ilgili olarak yapılan çalışmalar çok eski tarihlere dayanmakla birlikte, anne baba tutumları ile ilişkili olarak çocuğun sosyal ve kişisel gelişimine yönelik pek çok açıklama bulunmaktadır. Bunların ortak unsuru ise; anne baba tutumlarının çocuğun gelecek yaşamında karakterini, insan ilişkilerini etkileyecek çok önemli bir etken olduğudur (Senemoğlu, 2009, s.11).

Anne baba tutumları değişik kaynaklarda farklı şekilde sınıflandırılmıştır. Anne babaların çocuk yetiştirme tutumlarına bağlı kuramsal bir temel oluşturabilecek şekilde sınıflandırılması Baumrind (1971) tarafından yapılmıştır. Baumrind, anne, baba ve çocuk arasındaki iletişimi ebeveyn kontrolü, açıklık, olgunluk beklentisi ve bakım/destek boyutlarında ele almış ve bu boyutlara dayalı olarak da anne baba tutumlarını, otoriter, demokratik ve izin verici olmak üzere üç temel stilde ele almıştır (Sümer ve Güngör, 1999).

Jensen ise Baumrind' in sınıflamasını temel alarak, anne babanın sevgi gösterme davranışına dayalı olarak tutumları, yüksek sevgi göstermenin alt boyutunda; aşırı koruyucu, müsamahakâr, demokratik ve kuralcı tutumları sıralamıştır. Düşük sevgi gösterme boyutunun altında ise katı kontrollü, endişeli/sinirli, ihmal eden ve aşırı otoriter tutumlarını sıralamıştır (akt. Yücel, 2013). 
Maccoby ve Martin (1983; akt. Yılmaz, 2000) iki boyutlu bakış açısı modelinde Baumrind'den farklı olarak, anne baba tutumunu "duyarlılık/kabul" ve "talepkârlık/kontrol" olarak iki boyut açısından ele almış ve bu iki boyutun kesiştiği noktada dört farklı anne baba tutumu tanımlamışlardır. Bunlar; otoriter, demokratik, izin verici-müsamahakâr ve izin verici- ihmalkâr anne baba tutumlarıdır.

Schaefer (1959; Akt. Yılmaz, 2000), anne-baba tutumlarına ilişkin kontrol biçimlerini iki boyutlu; a) kontrole karşılık özerklik ve b) sevgiye karşlık düşmanlık) olarak özetlemekte ve 1) sevgi-özerklik, 2) sevgi-kontrol, 3) düşmanlık-özerklik ve 4) düşmanlık kontrol olarak (dört ayrı kontrol biçimi) tanımlamaktadır.

Lamborn ve arkadaşları (1991) geliştirdikleri “Anne-Baba Tutum Ölçeği" kategorik temelde anne baba tutumlarını a) otoriter, b) demokratik, c) müsamahakâr (izin verici-hoşgörülï) ve d) ihmalkâr (izin verici-ihmalkâr) olarak sinıflandırılmıştır (Yılmaz, 2000).

Kuzgun (1972) ise, ülkemizde Türk çocuklarının algıladığı anne baba tutumlarının farklı olup olmadığını belirlemek için 'Ana Baba Tutum Ölçeği' geliştirmiştir. Anne baba tutumların 'demokratik, ilgisiz ve otoriter' olarak tanımlamıştır. (yukarıda ebeveyn tutumları yetişkinlerin gözünde tanımlanırken, burada çocukların algıladı̆̆ı ebeveyn tutumlarından bahsedilmektedir. Mümkünse ve yayın varsa daha çok çocukların algıladığı ego durumlarından söz edilirse iyi olabilir)

Yavuzer ise anne baba tutumlarını; a) baskilı ve otoriter tutum, b) gevşek tutum, c) dengesiz ve kararsız tutum, d) koruyucu tutum, e) ilgisiz ve kayıtsız tutum, f) güven verici ve destekleyici tutum, g) hoşgörülü şeklinde sıralamıştır (Yavuzer, 1982, s.134,135).

Alan yazında ve kullanılan ölçeklerde anne baba tutumlarının sınıflandırması konusunda farklılık olsa da tutumlarda ağırlıklı olarak baskıcl/otoriter, aşırı koruyucu, demokratik ve aşırı serbest/gevşek ana baba tutumları üzerinde durulduğu görülmektedir. ( ebeveyn tutumları konusundaki sınıflandırmalara biraz fazla yer verilmiş. Belki biraz kısaltılabilir. Bunun yerine ebeveyn tutumları ile çocukların ego durumları arasındaki ilişki konusunda literatür bilgisi verilse yazı daha anlamlı olabilir. Çünkü yazının konusu bu durum) 
Baskıcı ve Otoriter Anne Baba Tutumu: Geleneksel Türk aile yapısında sık sık karşılaşılan bir tutumdur. Anne babanın uyguladığ1 katı disiplin yüzünden çocuğun her kurala uymak zorunda bırakıldığı ve çocuğun kişiliğine önem verilmeyen bir tutumdur (Dabak, 2007, s.5).

Bu tutumun temel niteliği çocuğa karşı gösterilen baskıdır. Anne baba çocuklarının kesin olarak hâkimi olduklarına inanıp, hiç açıklama yapmadan konulan kurallara itaatle koşulsuz uyulmasını beklemektedirler (Gümüş ve ark., 2011, s.425; Yavuzer, 1998, s.28). Otoriter ebeveynler, çocuklarını sevmektedir ancak sevgilerini pekiştireç olarak onlarda görmek istedikleri davranışların geliştirilmesinde kullanırlar. Çocuktan mutlak uyum beklemekle birlikte kendilerini toplumsal otoritenin temsilcisi olarak görürler (Cüceloğlu, 1992, s.59).

Anne babanın beklediği temel davranış olan itaat sağlanmadığında fiziksel ceza da uygulanır. Şımaracağı kaygisıyla çocuğun göstermiş olduğu olumlu davranış ödüllendirilmez, sevgi dile getirilmez ve belli edilmez. Bu tutuma sahip olan ebeveynlerin çocukları dışlanma, cezaland1rılma, azarlanma ve reddedilme davranışlarına maruz kalırlar (Kulaksızoğlu, 2011, s.122). Çocuğu baskı altında tutmak ve itaat ettirmek için utandırma, aşağılama ve dalga geçme gibi yöntemleri çok sık kullanmaktadirlar.

Aşırı Koruyucu Anne Baba Tutumu: Bu tutumun temel özelliklerinden birisi, çocuğun kendi başına karşılayabileceği ihtiyaçlarını bile anne babanın üstlenmesi ve çocuğa sorumluluk verilmemesidir. Çocukların bireyselleşme çabaları engellenmekle birlikte, dış dünyada karşılaşılabilecek tehlikeli durumlar abartılı olarak anlatılıp aile çocuğu eve bağlamaya çalışmaktadır. Anne babalar bu tutum sayesinde ergenlik döneminde psikososyal olgunluğun gelişimini ve bağımsız bir birey olabilmeyi engellemekte, sosyalleşme davranışlarını olumsuz etkilemektedirler (Kulaksızoğlu, 2011, s.120-121).

Demokratik Anne Baba Tutumu: Demokratik ailelerde, bireyler sevgi ortamında yetiştirilerek, fikirlerine saygı duyulmaktadır. Kararlar birlikte alınıp, çocuğun duygularına değil sadece davranışlarına sınırlamalar getirilmektedir. Eleştiriler çocuğun kişiliğine değil yaptığı işe yöneliktir. Anne babalar çocuklarını ayrı bir kişi olarak kabul ederek onlara değer 
verir ve özerk, bağımsız bir kişi olarak gelişmesine destek olurlar (Çağdaş, 2002).

Tutarsız/ilgisiz/aşırn gevşek/dengesiz/kararsız Anne Baba Tutumu: Anne baba ve çocuk arasında iletişim kopukluğu söz konusudur. İlgisiz tutumda çocuğa düşen ilgi ve sevgi payı azdır. Sorumsuzluk ve ilgisizlik sonucunda bu tutumda disiplinsizlik söz konusu olmaktadır (Gümüş ve ark., 2011).

Bu gruba giren anne babalar için çocuğun varlığı ya da yokluğu önemli değildir. Anne baba çocuğu yalnız bırakma, görmezlikten gelme gibi dışlayıcı örüntülerde bulunabilmektedirler (Cüceloğlu, 1993, s.51).

İlgisiz anne babalar denetlemede yetersiz oldukları için çocuklarının nerede olduklarını ve ne yaptıklarını bilmezler. Çocuklarına yol gösterip onları yönlendirmez, çocuğun düşüncelerine önem vermezler. Bu anne baba tutumu düşük benlik saygısının oluşmasına neden olmaktadır (Hart, 1987, s.123).

Bu tutumun en önemli özelliği ebeveynlerin çocuklarının yaptıklarına karışmıyor olmalarıdır. Çocukların yaptıkları hoş karşılanmakla birlikte aralarındaki ilişki ve duygusal bağları zayıftır. Hiçbir şekilde denetim altında olmayan çocuk, aile otoritesi eksikliği içindedir (Mansager ve Volk, 2004, s.7; Aydoğmuş ve ark., 2001, s.127).

\section{Anne Babalık Bilgi Düzeyi}

Anne babalık bilgi düzeyi ile; anne baba adaylarının ya da anne babaların, hamilelik döneminden itibaren, ergenlik dönemi sonuna kadar, çocuklarını fizyolojik, biyolojik, psikolojik ve sosyal gelişimleriyle ilgili hangi türde ve ne düzeyde bilgi sahibi oldukları kastedilmektedir (Özerk, 2006).

Özerk (2006), geliştirdiği Anne Babalık Bilgi Testi (ABBT)’ nde, bilgi türlerini, a) Magazinsel, b) Geleneksel ve c) Bilimsel kategorilerde; anne babaların bilgi düzeylerini de a) Hamilelik, b) Bebeklik, c) Çocukluk ve d) Ergenlik dönemlerine ilişkin olarak dört boyutta ele almıştır.

Huzurlu bir aile ortamına, mutlu bir yaşantıya ve sağlıklı çocuklara sahip olmak için, anne ve babaların yapmaları gereken çok önemli görevler bulunmaktadır. Bunlar anne ve babanın olumlu davranışları, bilinçli yaklaşımları ve de özenli hareketlerinden oluşmaktadır (Ertuğrul, 2005). 
Bu nedenle genel anlamda çocuğun gelişim evrelerine ve bu evrelerin davranış kalıplarının psikolojik ve fiziki değişim ve dönüşümü hakkında bilgi sahibi olmak gerekmektedir (Ünlü, 2002, s.105).

\section{Yöntem}

\section{Araştırma Yöntemi}

Araştırma betimsel bir araştırma olup, ilişkisel tarama modeli kullanılmıştır. Örnekleme yöntemi kümeleme oransız random örneklemedir. Araştırmaya katılan 13-18 yaş grubu 130 ergene kendilerinde algıladıkları özelliklerin işaretlenmesi istenerek, Transaksiyonel Analiz Kuramı bağlamında Ego Durumları Ölçeği (EDÖ) uygulanmıştır.

Öğrencilerin anne babalarından oluşan 130 ebeveyne de veri toplama araçları olarak geçerlik ve güvenirliğe sahip olan Anne Babalık Bilgi Testi (ABBT) ve Aile Hayatı Çocuk Yetiştirme Tutum Ölçeği (PARI, Parental Attitude Research) uygulanmıştır. Ayrıca araştırmacı tarafından geliştirilmiş olan Demografik Bilgi Formu verilerek doldurulması sağlanmıştır.

\section{Evren ve Örneklem}

Araştırmanın evrenini Düzce ili ile Akçakoca, Cumayeri ve Çilimli ilçelerinde bulunan ortaöğretim (lise) düzeyinde öğrenim gören öğrenciler ve bu öğrencilerin aileleri oluşturmaktadır. Örneklem, 130 anne baba ve 130 öğrenci olmak üzere 260 kişiden oluşmaktadır. Örnekleme yöntemi kümeleme oransız random örneklemedir ve ilişkisel tarama modelindedir.

\section{Veri Toplama Araçları}

Araştırmada, geçerlilik, güvenilirlik ve standardizasyon çalışması yapılmış Ego Durumları Ölçeği (EDÖ) (Ek:1), Anne Babalık Bilgi Testi (ABBT) (Ek: 2), Aile Hayatı Çocuk Yetiştirme Tutum Ölçeği (PARI, Parental Attitude Research) (Ek:3) ve araştırmacı tarafından oluşturulmuş olan Kişisel Bilgi Formu (Ek:4) kullanılmıştır. 
Ego Durumları Ölçeği (EDÖ): Ölçeğin orijinali Williams tarafından 1978'de geliştirilmiş ve Arı (1989) tarafından Türk kültürü için yeniden geliştirme çalışmaları yürütülmüştür.

Ölçek, insanı tanımlayan 95 sıfattan oluşan bir listeden oluşmaktadır. Ölçeğin geçerlik çalışmalarında, mantıksal ve istatistiksel yaklaşımdan yararlanılmıştır. Mantıksal geçerlik ile ilgili olarak uzman kanısına başvurulmuştur. Ölçeği oluşturan sıfatların puanlanmasında yararlanılan altı hakemin değerlendirmeleri arasındaki yüksek tutarlılık, ölçeğin mantıksal geçerliği için önemli bir kanıt sayılmıştır.

Ölçeğin benzer ölçekler geçerliği, Akkoyun ve Bacanlı (1988) tarafından Türkçe' ye uyarlanan 'Gough ve Heilbrun Sıfat Tarama Listesi' kullanılarak gerçekleştirilmiştir. Her iki ölçeğin benzer alt ölçekleri arasında Eleştirel Ebeveyn için $r=0.87$, Koruyucu Ebeveyn için $r=0.91$, Yetişkin için $r=0.93$, Doğal Çocuk için $r=0.76$ ve Uygulu Çocuk için $r=0.70$ ' lik korelasyon katsayıları bulunmuştur. Güvenirlik ile ilgili çalışmalarda ise, testin aralıklı tekrarı yönteminden yararlanılmıştır. İki uygulamadan elde edilen ego durumu puanları arasında Eleştirel Ebeveyn için $r=0.73$, Koruyucu Ebeveyn için $r=0.83$, Yetişkin için $r=0.81$, Doğal Çocuk için $r=$ 0.77 ve Uygulu Çocuk için $r=0.74$ 'lük tutarlılık katsayıları elde edilmiştir. Tüm bu veriler ölçeğin geçerli ve güvenilir bir ölçme aracı olduğuna işaret etmektedir (Bozanoğlu ve Özerk, 2017; Özerk ve Mercanlığlu, 2017; Özerk, Ada ve Özerk, 2018).

Aile Hayatı Çocuk Yetiştirme Tutum Ölçeği (PARI): Araştırmada ele alınan, çocuk yetiştirmede ana-baba tutumlarına ilişkin veriler PARI (ek: 2) aracı ile elde edilmiştir. PARI, Schaefer ve Bell tarafından geliştirilen, Le Compte, Le Compte ve Özer (1978) tarafından Türkçe' ye çevrilerek, geçerlilik ve güvenilirlik çalışmaları yapılmış bir ölçektir.

Ölçeğin orijinali 115 maddeden oluşmaktadır. Bu araştırmada kullanılmış olan, kısaltılmış formu ise 60 maddeyi içermekte ve 5 faktörden oluşmaktadır. Maddelerde olumlu ve olumsuz ifadeler yer almaktadır. Deneklerden 'Daima uygun buluyorum', 'Genellikle uygun buluyorum', ‘Biraz uygun buluyorum' ve 'Hiç uygun bulmuyorum' şeklinde yer alan 4' lü derecelemeden birini işaretlemeleri istenmektedir.

PARI, hem ana-babalara hem de çocuklara uygulanabilen bir araçtır. 1., 2. ve 5. faktörler ana-baba tutumlarını doğrudan; 3. ve 4. faktörler ise 
aile içi ve eşler arası ilişkiyi ele alarak çocuğu dolaylı yoldan etkileyen faktörleri içermektedir.

Aracın Türkçe' ye ilk uyarlama çalışmaları Le Compte ve arkadaşları tarafından 1978' de yapılmıştır. Maddeler bir grup psikolog tarafından Türkçe' ye ve İngilizce' ye çevrilmiş, son düzeltmelerden sonra form Ankara' da 3 hafta ara ile bir grup kız ve erkek öğrenciye uygulanmıştır. Test, tekrar test korelasyonları .58 ve .88 arasında bulunmuştur. Form daha sonra yüksek, orta ve düşük sosyoekonomik düzeyi temsil eden 129 anneye uygulanmıştır. Annelerin yanıtlarından elde edilen alfa katsayısı (iç tutarlılık) .64 olarak bulunmuştur. 115 maddeden madde güvenilirliği yüksek ve faktör yükleri açık olan 60 ifade seçilmiştir. Bu kısaltılmış formun alfa katsayısı .81 olarak bulunmuştur. 5 faktörün alfa katsayısı ise .59 ile .90 arasında değişmektedir (Le Compte ve ark., 1978; Öner, 1997).

Anne Babalık Bilgi Testi (ABBT): ABBT, Özerk (2006) tarafından geliştirilmiştir. Test, ana-baba tutumları kuramcılarından ve ana-baba tutumların inceleyen araştırmacılardan Gullo (1988)' nun soru listesinden (0-14 aylık bebeklerin motor, sosyal, bilişsel ve dil gelişimlerine ilişkin) ve Lally, Lerner ve Hurvitz (2001)' in 0-6 yaş arası çocuklara ilişkin ebeveynlere verilen soru listesinden yararlanılarak doğum öncesinden itibaren ergenlik dönemi sonuna kadar ve ek olarak ergenlik dönemi sonuna kadar olan tüm gelişimsel alanları içermektedir.

ABBT, doğum öncesi, bebeklik, çocukluk ve ergenlik olmak üzere dört temel kategoride ifadeleri içermektedir.

Toplam 70 maddeden oluşan ve yönergesi de hazırlanan ölçek (ABBT = Ana-babalık Bilgi Testi) deneme formu, geçerlilik ve faktör analizi çalışması için, araştırmanın gerçekleştirileceği gruba benzer özellikler taşıyan (yaş, ögrenim durumu, sahip olunan çocuk sayısı vb. özellikler bakımından) 45’ i erkek, 65' i kadın olmak üzere toplam 110 ana-babaya uygulanmiştır.

ABBT gerek deney ve gerekse kontrol gruplarına, küçük gruplar halinde ve araştırmacının kendisi tarafından yapılmıştır.

Madde seçimi için önce maddelerin her birisi, ayırt ediciliği olup olmadığını belirlemek amacıyla toplam puanla korelasyonları bakımından ve madde güçlük düzeyi bakımından hem point-biserial (nokta-çift serili) korelasyon katsayılarıyla hem de alt-üst grup ayırt ediciliği ile incelenmiştir. 
Yapılan point-biserial korelasyon katsayılarına dayalı madde ayırt edicilik indeksi ve alt-üst grup ayırt ediciliği indeksi hesaplamaları sonucunda toplam 11 maddenin, ayırt edicilik katsayılarının beklenen (istenilen) değer olan $0.30-0.70$ arası değerlerden uzakta ve çok düşük ( $0.10^{\prime}$ un altında değerler) olduğu bulunmuş ve bu nedenle ölçekten çıkartılmasına karar verilmiştir.

Madde güçlük indeksi bakımından maddeler incelendiğinde ise toplam 7 maddenin güçlük indeksinin beklenen değerin (0.50 civarında) çok üzerinde ( 0.90 ve üzerinde değerler) olduğu bulunmuş ve bu 7 maddenin de ölçekten çıkartılmasına karar verilmiştir.

Kalan maddeler (toplam 52 madde) ölçeğin faktör yapısını (temel boyutlarını) belirlemek amacıyla faktör analizine sokulmuştur. Ölçek maddeleri Doğru =1 (bir) ve Yanlış = 0 (sıfır) şeklinde puanlandığından bu maddelere dayılı olarak yapılacak faktör analizinin tetrakorik korelasyon katsayılarına dayalı faktör analizi olması gerektiği Lord ve Novick (1968) ve Hambleton, Swaminathan ve Rogers (1991) tarafından bildirilmiştir. Maddeler arası tetrakorik korelasyon katsayıları Statistica 4.5 programı aracılığı ile hesaplanmış ve tetrakorik korelasyonlara dayanan temel bileşenler analizi (faktör analizi) yapılmıştır. Analiz sonucunda bazı maddelerin iki faktörde birden yer aldığı görülmüş ve faktör yapısını düzenlemek amaciyla varimax rotasyonu uygulanmıştır. Uygulanan rotasyon sonucunda ölçeğin maddelerinin üç temel faktörde (boyutta) toplandığ 1 gözlenmiştir (Özerk,2006).

Faktör analizine giren maddelerden de toplam 5 maddenin yeteri kadar (herhangi bir faktöre dahil olacak kadar) faktör yükü alamadığı görülmüştür. Bu 5 madde de ölçekten çıkartıldıktan sonra yinelenen rotasyonlu faktör analizi sonucunda nihai ölçeğe ulaşılmıştır. Nihai ölçek 47 maddeden oluşmuştur. Yapılan analizler sonucunda kalan 47 maddenin faktör analizi sonuçlarına dayalı olarak ABBT' nin faktör analiziyle belirlenen üç faktörüne, maddelerin (ifadelerin) özellikleri dikkate alınarak;

I. Faktör' e 'Geleneksel Bilgi',

II. Faktör' e 'Magazinsel Bilgi',

III. Faktör' e ise 'Bilimsel Bilgi' adları verilmiştir.

Bu maddelerden oluşan nihai ölçeğin güvenilirlik katsayısı (KR-20 güvenilirlik katsayısı) 0,93 olarak bulunmuştur. Öyle görünmektedir ki ölçek 
bu haliyle çok yüksek bir iç tutarlılık göstermektedir. Bu anlamıyla da güvenilirliği oldukça yüksektir.

Nihai olarak 47 maddeden oluşan ABBT' nin ayırt edicilik özelliğini görebilmek için deney ve kontrol grupları oluşturularak ön test son test uygulaması gerçekleştirilmiştir. Yapılan analizler sonucunda ABBT' nin deney ve kontrol gruplarını son test puanlarına bağlı olarak istatistiksel olarak anlamlı düzeyde ayırt ettiği görülmüştür $(t=-36,90 ; p<0,01)$.

Kişisel Bilgi Formu: Araştırmanın örneklemini oluşturan katılımcıların demografik özelliklerini tespit etmek amacı ile araştırmacı tarafından hazırlanan Kişisel Bilgi Formu (Ek.1) kullanılmıştır. Bu formda katılımcılara; yaş, cinsiyet, meslek, iş, öğrenim durumu, medeni durum, çalışmaya konu olan çocuğun cinsiyeti ve bulunduğu sınıf, ana - baba öğrenim durumu, kardeşlerinin arasında kaçıncı çocuk oldukları ve kardeşlerinin cinsiyetleri hakkında bilgi toplamaya yönelik sorular sorulmuştur.

\section{Verilerin Toplanması}

Veri toplama araçları gönüllülük esasına göre araştırmaya katılmak isteyen öğrenci ve öğrencilerin anne babalarına uygulanmıştır. Uygulamadan önce araştırmacı kendisini tanıtmış, araştırmanın amacı hakkında ve Ego Değerlendirme Ölçeği ile Kişisel Bilgi Formu' nu nasıl doldurmaları gerektiği konularında bilgilendirme yapılmıştır. Ölçme araçları doldurulmadan önce hem öğrenci olan katılımcılar hem de öğrencilerin anne babası konumunda olan katılımcılar, araştırmanın amacı, uygulama şekli, ölçekleri nasıl doldurmaları gerektiği, kişisel bilgilerin gizliliği (tüm formlardaki talimat ve bilgilendirme kısmında yer aldığı üzere), katılımın gönüllülük gerektirdiği, isteyenin ölçekleri doldurmaya başlamış olsa bile vazgeçebileceği konusunda bilgilendirilmiştir.

Her iki gruba da zaman kısıtlamalarının olmadığı bilgisi verilerek daha rahat yanıtlamaları amaçlanmıştır. Öğrencilere EDÖ, anne babalara ise s1rasıyla Kişisel Bilgi Formu, PARI, ABBT ve verilerek doldurmaları sağlanmiştır. 
Veri toplama araçları öğrencilere özellikle kendilerini daha rahat hissedecekleri ve ders kaygısı yaşamadan rahatlıkla yanıtlayabilecekleri Rehberlik etkinliğinde yüz yüze etkileşim ortamında verilmiş ve araştırmacı tarafından da toplanmıştır. Anne babalara ise okulun düzenlediği seminerler öncesinde yine yüz yüze etkileşim ortamında verilmiş ve yine araştırmacı tarafından toplanmıştır.

\section{Verilerin Analizi}

Elde edilen verilerin analizi SPSS 16.0 Windows paket programiyla ve Microsoft Office Excel programı kullanılarak analiz edilmiş olup Tek Yönlü Varyans Analizi, Bağımsız Guruplar T-testi, Regresyon Analizi, Ki Kare Uyum İyiliği (Goodnes of fit) ve analiz sonucu elde edilen değerin anlamlı çıkması durumunda ise Scheffe Post-hoc testlerinden yararlanılmış, tüm verilerin anlamlılık düzeyi $\mathrm{p}<0.05$ düzeyinde sınanmıştır.

\section{Bulgular}

Katılımcı anne babaların büyük çoğunluğu annelerden $(\% 89,2)$ oluşmuştur ve büyük çoğunluğu 41-50 yaş (\%48,5) grubunda yer almıştır. Öğrenim düzeyleri bakımından ise; birinci sırada $(\% 44,6)$ ilkokul, ikinci sırada $(\% 24,6)$ üniversite, üçüncü sırada $(\% 18,5)$ ortaöğretim yer almıştır. Anne babaların çalışma durumları bakımından ise büyük çoğunluğu çalışmayanlar $(\% 76,2)$ oluşturmuştur. Çalışanların oranı ise \%23,1' dir. Medeni durum bakımından anne babaların \%55'inin evli, \%42,6' sının ise bekar olduğu görülmüştür. Anne babaların sahip oldukları çocuk sayısına bakıldığında ise, iki çocuğa sahip olanların ilk sırada $(\% 34,6)$, beş ve daha fazla sayıda çocuğa sahip olanların ikinci sırada (\%21,5), tek çocuğa sahip olan anne babaların ise son sırada $(\% 9,2)$ yer aldığı görülmüştür.

Öğrenci katılımcıların büyük çoğunluğunu kız öğrenciler $(\% 63,8)$ oluştururken erkek öğrencilerin \%35,4 oranında olduğu görülmüştür. 
Tablo 1. Örneklem Grubunun Ana Babalık Konusunda Farklı Alanlardaki Bilgi Düzeylerinin Frekans ve Yüzdelikleri

\begin{tabular}{|c|c|c|c|c|c|c|c|c|c|c|}
\hline \multirow{3}{*}{$\begin{array}{l}\text { Bilgi Kay- } \\
\text { nağ } 1\end{array}$} & \multicolumn{10}{|c|}{ Bilgi Düzeyi } \\
\hline & \multicolumn{2}{|c|}{ Çok Düşük } & \multicolumn{2}{|c|}{ Düşük } & \multicolumn{2}{|c|}{ Orta } & \multicolumn{2}{|c|}{ Yüksek } & \multicolumn{2}{|c|}{$\begin{array}{l}\text { Çok Yük } \\
\text { sek }\end{array}$} \\
\hline & & $\%$ & $f$ & $\%$ & $f$ & $\%$ & $f$ & $\%$ & $f$ & $\%$ \\
\hline Hamilelik & 2 & 1,5 & 18 & 13,8 & 65 & 50,0 & 44 & 33,8 & 1 & 8 \\
\hline Bebeklik & 1 & 8 & 17 & 13,1 & 67 & 51,5 & 45 & 34,6 & --- & \\
\hline Çocukluk & --- & & 20 & 15,4 & 63 & 48,5 & 41 & 31,5 & 6 & 4,6 \\
\hline Ergenlik & 1 & ,8 & 4 & 3,1 & 8 & 6,2 & 78 & 60,0 & 39 & 30,0 \\
\hline Geleneksel & 2 & 1,5 & 19 & 14,6 & 45 & 34,6 & 58 & 44,6 & 6 & 4,6 \\
\hline Magazinsel & 32 & 24,6 & 57 & 43,8 & 36 & 27,7 & 5 & 3,8 & --- & \\
\hline Bilimsel & --- & & 3 & 2,3 & 19 & 14,6 & 61 & 46,9 & 47 & 36,2 \\
\hline
\end{tabular}

Tablo 1 incelendiğinde araştırmaya katılan anne babaların Anne Babalık Bilgi testi sonuçlarına göre, testin dört alt alanına ilişkin olarak; hamilelik dönemine ilişkin bilgi düzeylerinin ağırlıklı olarak orta düzeyde olduğu (\%50), çok yüksek (çok yeterli) düzeyde sayılabilecek bilgilerinin ise $\% 0,8$ düzeyinde olduğu, $\% 13,8$ düzeyinde düşük (yetersiz) ve $\% 1,5$ düzeyinde de çok düşük (çok yetersiz) bilgiye sahip oldukları görülmektedir. Bebeklik dönemine ilişkin bilgi düzeylerinin ise hamilelik dönemine benzer şekilde ağırlıklı olarak \%51,5 ile orta düzeyde, $\% 13,1$ ile düşük ve \%1,5 ile çok düşük düzeyde oldukları, çok yüksek düzeyde ise puana sahip olmadıkları görülmektedir. Çocukluk dönemine ilişkin olarak \%48,5 ile orta $\% 4,6$ ile çok yüksek düzeyde oldukları ve çok yetersiz düzeyde de puana sahip olmadıkları görülmektedir. Ergenlik dönemine ilişkin olarak da diğer dönemlerden farklı olarak \%60 oranında yüksek, \%3,1 düşük düzeyde bilgiye sahip oldukları ve çok düşük düzeyden puan almadıkları görülmektedir.

Anne babaların bu bilgi düzeylerinin ne tür bilgiler olduğuna bakıld1ğında bilimsel bilgi düzeyi bakımından $\% 46,9$ ile yüksek ve $\% 2,3$ ile düşük düzeyde olduklarl; geleneksel bilgi bakımından ise \%44,6 ile yüksek, \%14,6 ile düşük ve \%1,5 ile çok düşük düzeyde puan aldıkları; magazinsel bilgi bakımından ise $\% 43,8$ ile düşük $\% 24,6$ ile çok düşük ve $\% 3,8$ ile yüksek bilgi düzeyinde puanlara sahip oldukları görülmektedir. 
Tablo 2. Ana baba Tutumları Puanları Minimum, Maksimum, Ortalama ve Standart Sapmalart

\begin{tabular}{lcclll}
\hline Tutum & & & & & $\begin{array}{l}\text { Standart } \\
\text { Sapma }\end{array}$ \\
\hline Aşırı Koruyucu Annelik & 130 & 1,57 & 4,00 & 3,0577 &, 51608 \\
$\begin{array}{l}\text { Demokratik Tutum ve Eşitlik Ta- } \\
\text { nıma }\end{array}$ & 130 & 1,67 & 4,00 & 2,8880 &, 44390 \\
Ev Kadınlığı Rolünü Reddetme & 130 & 1,38 & 3,77 & 2,5438 &, 52358 \\
Evlilik Çatışması & 130 & 1,17 & 4,00 & 2,5397 &, 63517 \\
Baskıcı- Disiplinli & 130 & 1,38 & 3,81 & 2,5279 &, 51274 \\
& & & & & \\
\hline
\end{tabular}

Tablo 2' de örneklem grubunun PARI envanterinin alt faktörlerinden aldıkları puanların ranj (minimum-maksimum), ortalama ve standart sapmaları görülmektedir. En yüksek ortalama Aşırı Koruyucu Annelik boyutunda görülürken $(3,05)$, bunu Demokratik Tutum ve Eşitlik Tanıma boyutu $(2,88)$ izlemekte, en düşük ortalama Baskıc1-Disiplinli boyutunda görülmektedir.

Tablo 3. Öğrencilerin Ego Durumlarnna İlişkin Ki Kare Uyum İyiliği Analizi Sonucu

\begin{tabular}{lll}
\hline Ego durumları & Gözlenen birey sayısı & Beklenen birey sayısı \\
\hline Eleştirel Ebeveyn & 4 & 26 \\
Koruyucu Ebeveyn & 79 & 26 \\
Yetişkin & 13 & 26 \\
Uygulu Çocuk & 3 & 26 \\
Doğal Çocuk & 31 & 26 \\
Toplam & 130 & 130 \\
\hline & & \\
Ki Kare değeri & Serbestlik derecesi & Anlamlılık \\
154,462 & 4 &, 000 \\
\hline
\end{tabular}

Tablo 3, ego durumları frekanslarının istatistiksel beklenti frekanslarına uyumunu göstermektedir. Ego durumları frekanslarının örneklemde eşit dağılıp dağılmadığını belirlemek amacıyla Ki Kare Uyum İyiliği (Goodnes of Fit) analizi yapılmıştır. Analiz sonucu ego durumları frekans dağllımının istatistiksel olarak anlamlı derecede birbirinden farklı olduğunu göstermektedir, X2 (4, N = 298) = 261,698, p < .05. Uygulu Çocuk ve Eleştirel Ebeveyn ego durumu oldukça az görünürken en yüksek frekans Koruyucu Ebeveyn ego durumunda gözlenmiştir. 
Tablo 4. Anne babalarının, çocuk yetiştirmeye ilişkin tutumları ve anne babalık düzeyleri arasındaki ilişki

\begin{tabular}{lll} 
& $(1)$ & $(2)$ \\
\hline (1) Çocuk yetiştirmeye ilişkin tutumlar & 1 & $-.449^{* *}$ \\
(2) Anne babalık bilgi düzeyleri & & 1 \\
\hline${ }^{* *} \mathrm{p}<.01$ &
\end{tabular}

Tablo 4 incelendiğinde anne-babalarının, çocuk yetiştirmeye ilişkin tutumları ile anne babalık bilgi düzeyleri arasında $(\mathrm{r}=-.449 ; \mathrm{p}<.01)$ negatif yönlü, anlamlı bir ilişki bulunmaktadır. Buna göre, (PARİ ölçeğinde yüksek puanların olumsuz tutumlara karşıllı geldiği hatırda tutularak) annebabalarının, çocuk yetiştirmeye ilişkin tutum puanları arttıkça anne babalık bilgi düzeylerinin düşeceği, aynı şekilde anne babalık bilgi düzeyleri arttıkça anne-babalarının çocuk yetiştirmeye ilişkin sağlıksız tutumlarının düşeceği söylenebilir.

Tablo 5. Anne babaların çocuk yetiştirmeye ilişkin tutumlarının öğrenim durumuna göre farklılaşmasına Yönelik Tek Yönlü Varyans Analizi Sonuçları

\begin{tabular}{lllllll}
\hline & \multicolumn{2}{l}{ Kareler } & \multicolumn{2}{l}{ top- } & \multicolumn{2}{l}{ Kareler orta- } \\
lamı & & sd & laması & F & P & \multicolumn{2}{l}{$\begin{array}{l}\text { Post Hoc } \\
\text { Scheffe }\end{array}$} \\
\cline { 2 - 7 } Gruplar arası & 9229,665 & 3 & 3076,555 & 9,742 &, 000 & \\
Gruplar içi & 38212,527 & 121 & 315,806 & & & $1-4$ \\
Toplam & 47442,192 & 124 & & & & \\
\hline$p<, 05$ & & & & &
\end{tabular}

Not: Kategoriler: 'Illkokul'=1; 'Ortaokul'=2; 'Lise'=3; 'Üniversite' $=4$

Tablo 5'e göre, Anne babaların çocuk yetiştirmeye ilişkin tutumlarının öğrenim durumu bakımından $\left(\mathrm{F}_{(3-121)}=9,74 \mathrm{p}<, 01\right)$ anlamlı farklılık gösterdiği görülmektedir. Farkın kaynağını belirlemek için yapılan post-hoc Scheffe analizleri sonucunda 'İlkokul' mezunlarının puan ortalamasının ( $\bar{X}=115,59)$ 'Üniversite’ mezunlarının puan ortalamasından $(\bar{X}=84)$ daha yüksek olduğu görülmektedir. Yani farkın kaynağının bu puan yüksekliği olduğu görülmektedir. Burada yine PARI puanlarının yüksekliğinin olumsuz tutumu işaret ettiğinin hatırlanmasında yarar vardır. 
Tablo 6. Anne babaların çocuk yetiştirmeye ilişkin tutumlarının anne babanın çalışıp çalışmadığına göre farklılaşma durumuna yönelik bă̆ımsız gruplar t-testi sonuçları

\begin{tabular}{|c|c|c|c|c|c|c|c|}
\hline Değişken & İş Durumu & $\mathbf{N}$ & $\bar{X}$ & SS & Sd & $\mathrm{T}$ & $\mathbf{P}$ \\
\hline \multirow[t]{2}{*}{ Aşırı koruyucu annelik } & Çalışıyor & 30 & 38,34 & 8,16 & 127 & $-3,80$ & ,001 \\
\hline & Çalışmıyor & 99 & 44,54 & 7,67 & & & \\
\hline \multirow[t]{2}{*}{ Demokratik tutum } & Çalışıyor & 30 & 25,56 & 3,52 & 127 &,-60 &, 553 \\
\hline & Çalışmıyor & 99 & 26,06 & 4,11 & & & \\
\hline \multirow[t]{2}{*}{ Ev kadınlığ1 rolünü red } & Çalışıyor & 30 & 31,03 & 6,32 & 127 & $-1,84$ & ,068 \\
\hline & Çalışmıyor & 99 & 33,64 & 6,86 & & & \\
\hline \multirow[t]{2}{*}{ Evlilik çatışması } & Çalışıyor & 30 & 15,60 & 3,85 & 127 & $-3,60$ & ,001 \\
\hline & Çalışmıyor & 99 & 14,54 & 3,56 & & & \\
\hline \multirow[t]{2}{*}{ Bask1-disiplin } & Çalışıyor & 30 & 35,53 & 7,69 & 127 & $-3,90$ & ,001 \\
\hline & Çalışmıyor & 99 & 41,87 & 7,83 & & & \\
\hline \multirow[t]{2}{*}{ PARI toplam } & Çalışıyor & 30 & 97,40 & 21,08 & 127 & $-4,50$ & ,001 \\
\hline & Çalışmıyor & 99 & 114,85 & 17,83 & & & \\
\hline
\end{tabular}

$\mathrm{p}<.05$

Tablo 6'daki sonuçlara göre tutum ölçeğinden alınan toplam puanlar karşılaştırıldığında; çalışmayan anne babaların puan ortalamalarının çalışan anne babaların puan ortalamasından anlamlı derecede $(\mathrm{t}=-4,50 ; \mathrm{p}$ $<0.05)$ yüksek olduğu görülmektedir.

Ölçeğin alt faktörlerine bakıldığında çalışmayan anne babalar Aşırı Koruyuculuk $(\mathrm{t}=-3,08, \mathrm{p}<0.05)$, Evlilikte Çatışma $(\mathrm{t}=-3,60, \mathrm{p}<0.05)$ ve Bask1Disiplin $\mathrm{t}=-3,90, \mathrm{p}<0.05)$ alanlarında çalışan anne babalardan anlamlı derecede yüksek puan almışlardır.

Tablo 7. Anne babalarn çocuk yetiştirmeye ilişkin ana-babalık bilgi düzeyinin öğrenim durumuna göre farkhlaş̧masına Yönelik Tek Yönlü Varyans Analizi Sonuçları

\begin{tabular}{|c|c|c|c|c|c|c|}
\hline & \multicolumn{2}{|c|}{ Kareler top- } & \multicolumn{2}{|c|}{ Kareler orta- } & \multirow[b]{2}{*}{$\mathrm{p}$} & \multirow{2}{*}{$\begin{array}{l}\text { Post Hoc } \\
\text { Scheffe }\end{array}$} \\
\hline & lamı & sd & laması & $\mathrm{F}$ & & \\
\hline Gruplar aras1 & 551,141 & 3 & 183,714 & 8,96 & 000 & $4-1$ \\
\hline Gruplar içi & 2480,571 & 121 & 20,501 & & & 3-1 \\
\hline Toplam & 3031,712 & 124 & & & & \\
\hline
\end{tabular}
$\mathrm{p}<, 05$

Not: Kategoriler: 'Illkokul'=1; 'Ortaokul'=2; 'Lise'=3; 'Üniversite'=4

Tablo 7'ye göre, anne babaların çocuk yetiştirmeye ilişkin ana babalık bilgi düzeyinin öğrenim durumuna göre $\quad\left(\mathrm{F}_{(3-121)}=8,96 \mathrm{p}<, 05\right)$ anlamlı fark olduğu görülmektedir. Farkın kaynağını belirlemek için yapılan post- 
hoc Scheffe analizleri bu farkın, 'Üniversite’ mezunlarının ortalamasının ( $\bar{X}=31,27)$ 'Ilkokul' mezunlarının ortalamasından ( $\bar{X}=24,96)$; 'Lise' mezunlarının ortalamasının da ( $\bar{X}=28,62)$ 'Illkokul' mezunlarının ortalamasından $(\bar{X}=24,96)$ daha yüksek olmasından kaynaklandığını göstermiştir.

Tablo 8. Anne babaların çocuk yetiştirmeye ilişkin ana-babalık bilgi düzeyinin çalışıyor olup olmama durumuna göre farklılaşma durumuna yönelik bağımsız gruplar ttesti sonuçları

\begin{tabular}{|c|c|c|c|c|c|c|c|}
\hline Değişken & $\begin{array}{l}\text { Çalışma du- } \\
\text { rumu }\end{array}$ & $\mathbf{N}$ & $\bar{X}$ & SS & Sd & $t$ & $\mathbf{P}$ \\
\hline \multirow{2}{*}{$\begin{array}{l}\text { Ana-babalık bilgi dü- } \\
\text { zeyi }\end{array}$} & Çalışıyor & 30 & 29,57 & 4,32 & 127 & 3,21 & ,002 \\
\hline & Çalışmiyor & 99 & 26,31 & 5,01 & & & \\
\hline
\end{tabular}

Tablo 8 anne babalık bilgi düzeyleri bakımından çalışanlarla çalışmayanların puan ortalamasının bağımsız gruplar t-testi ile karşılaştırılmasının sonuçlarını içermektedir. Anne babalık bilgi düzeyi bakımından ortalamalar arasında çalışanların lehine anlamlı bir farklılık $(\mathrm{t}=3,21, \mathrm{p}<, 05)$ olduğu görülmektedir.

Tablo 9. Ana-babalık Bilgi düzeyinin Anne babaların çocuk yetiştirmeye ilişkin tutumların yordama gücü

\begin{tabular}{llllll}
\hline Değişken & $\mathrm{B}$ & $\begin{array}{l}\text { Standart } \\
\text { Hata }\end{array}$ & $\beta$ & $\mathrm{t}$ & $\mathrm{p}$ \\
\hline $\begin{array}{l}\text { Sabit } \\
\begin{array}{l}\text { Anne-baba } \\
\text { tutumu }\end{array}\end{array}$ & 158,778 & 8,563 & & & \\
\hline $\begin{array}{l}\mathrm{R}=.449 \\
F_{(1)}=32,355\end{array}$ & $-1,772$ &, 312 &,- 449 & $-5,688$ &, 000 \\
\hline
\end{tabular}

Tablo 9' da Ana-Babalık Bilgi düzeyinin anne babaların çocuk yetiştirmeye ilişkin tutumlarını yordama gücünü belirlemek amacıyla yapılan basit regresyon analizi sonuçlarına göre Anne-babalık Bilgi düzeyinin anne babaların çocuk yetiştirmeye ilişkin tutumlarını anlamlı düzeyde $\left(\mathrm{R}=.449, R^{2}=.202\right)$ yordadı $\breve{g} 1$ bulunmuştur $\left(F_{(1)}=32,355, \mathrm{p}=0,000\right)$. Anababalık Bilgi düzeyi Anne babaların çocuk yetiştirmeye ilişkin tutumlarındaki varyansın yaklaşık \%20'sini açıklamaktadırlar. 


\section{Tartışma ve Yorum}

Araştırmada anne babalar ve öğrenciler olmak üzere iki grup yer almıştır. Anne babalar bağlamında bakıldığında; anne babaların büyük çoğunluğunun (\%48,5) 41-50 yaş, grubunda olduğu görülmektedir. TÜİK verilerine göre, anne olma yaşı her geçen yıl az da olsa yükselmektedir. Örneğin 2001 yılında anne olma yaşı 26,2 iken 2016 yılında 28,1'e çıktığı, doğurganlık aralığ neklem grubumuzdaki annelerin oranının $\% 89,2$ olduğu göz önünde bulundurulduğunda 31-50 yaş grubu annelerin oranının \%96,8 olduğu görülmektedir. Bu bağlamda yine örneklem grubumuzdaki öğrencilerin 1318 yaş aralığında olduğu düşünüldüğünde annelere ilişkin bu frekans dağılımının TÜİK verileriyle örtüştüğü ve Türkiye genelini yansıttığı görülmektedir.

Anne babaların çalışma durumları bakımından ise büyük çoğunluğu çalışmayanlar $(\% 76,2)$ oluşturmaktadır ki örneklem grubunun \%89,2' sinin annelerden olduğu düşünüldügünde çalışmayanların da büyük çoğunluğunu annelerin oluşturacağı açıktır.

Anne babaların, anne babalık bilgi düzeylerinin türüne ve alanlarına bakıldığında, tablo 1' de görüldügü üzere; anne babaların, hamilelik döneminden ergenlik dönemi sonuna kadar olan dönemleri içeren anne babalık bilgileri düzey bakımından; toplam $\% 26,1$ oranında 'Çok Düşük' düzeydedir ve bu bilginin $\% 24,6$ ' s1 da magazinsel türde bilgidir. Toplam $\% 60,7$ oranında 'Yetersiz' düzeydedir ve bu bilgilerin \%43,8' i magazinsel, $\% 14,6^{\prime}$ sı geleneksel ve sadece $\% 2,3^{\prime}$ ü bilimsel bilgidir. Toplam $\% 40,8$ oranında ise 'Çok İyi' düzeydedir ve bu bilgilerin de '36,2' si bilimsel, \%4,6' s1 gelenekseldir.

Anne babaların sahip oldukları bilgilerin alanlar bakımından dağılımına bakıldığında, Hamilelik dönemine ilişkin bilgilerinin ağırlıklı olarak orta düzeyde (\%50), Bebeklik dönemine ilişkin bilgilerinin $\% 51,5$ oranında Orta düzeyde, Çocukluk dönemine ilişkin bilgilerinin \%48,5 oranında Orta düzeyde olduğu olduğu görülmektedir. En olumlu sayılabilecek bilgi düzeylerinin ergenlik dönemine ilişkin olduğu (\%30 çok iyi ve \%60 iyi düzeyinde), en olumsuz sayılabilecek alanın da çocukluk dönemine ilişkin olduğu (\%15,4 yetersiz ve $\% 48,5$ orta düzey) olduğu görülmektedir. 
Bu sonuçlar, Özerk' in (2006) yaptığı çalışma bulgularıyla oldukça örtüşmektedir. Üstelik geçen sürede (yaklaşık 15 yıllık sürede) anne babaların bilgi düzeylerinin pek değişmediğini ortaya koyması bakımından da düşündürücü ve anlamlıdır. Tutumların düşünce, duygu ve davranışöğelerinden oluşan güçlü bir bütünlük olduğu tutum değişiminde (özellikle kalıplaşmış tutumların değişmesinde) en önemli aşamanın bilgi öğesinde başlaması gerektiği, (Kağıtçıbaşı, 2003:85-108) göz önünde bulundurulduğunda çocuk yetiştirmeye ilişkin anne baba tutumlarının sağlıklılığ1 için bilimsel verilere dayalı anne babalık bilgi düzeyinin ne kadar önemli olduğu açıç̧a görülmektedir.

Kaya' nın (1994) eğitim verilen anneler ve verilmeyen anneler ile yaptığı çalışmada, eğitim verilen annelerin sağlıksız tutumlarında anlamlı derecede farklılık görüldüğünün bulgulanması Mızrakçı' nın (1994) yaptıkları çalışmada da eğitim düzeyi arttıkça demokratik tutumun arttığı ve bunun tersine otoriter ve aşırı koruyucu tutumun azaldığının bulgulanması ve Yeşilyaprak' in (1998) yaptığı çalışmada annenin koruyucu tutumu ile lise öğrencilerinin içsel denetimi (otokontrol) arasında negatif yönde anlamlı ilişkinin bulgulanması, bu çalışmanın bulgularıyla örtüşmekte ve bu bulgular, tutum değişiminde bilginin önemine ilişkin yukarıda yapilan vurguyu desteklemektedir.

Araştırmada, anne baba tutumlarında aşırı koruyucu tutumun en yüksek ortalamaya sahip olduğu $(3,05)$, bunu sirasiyla demokratik tutum $(2,88)$ ve baskıcı-disiplinli tutumun $(2,52)$ izlediği bulgulanmıştır.

Anne baba tutumları ile çocuk ve gençlerde davranış problemleri ve davranış bozukluklarıyla ilişkisinin araştırıldığı pek çok çalışma sonuçlarında (Baldwin,1948; akt. Ş. Erginbay; 2014; Drews,1957; Teahan,1963, Nichols 1963; Akbaba, 1988; Eastman, 1988; Diaz, 1989; Güney, 1989; Berber, 1990; Aksaray, 1992; Bostan, 1993; Akbağ, 1994; Yücedağ, 1994; Yeşilyaprak, 1998; Tuzgöl, 2000; Sipahioğlu, 2002; Peksaygılı ve Güre, 2008; Kula, 2008; Özdemir, 2009; Avc1, 2010; Vidinlioğlu, 2010; Yaşa, 2012), koruyucu, kollayıcı tutum ile baskıcı/disiplinli anne baba tutumunun sağlıksız tutum olduğunun ortaya konmuş olması araştırmanın bu bulgusuyla örtüşmektedir.

Aynı zamanda, çocuklarda ve ergenlerde görülen davranım bozukluklarında, bilinen en önemli etmenin psikososyal etmenler olduğu ve bu 
etmenler arasında da ebeveyn tutumlarının belirleyici bir role sahip olduğunun uzmanlar tarafından (Burke ve ark., 2002; Capaldi and Patterson, 1996; Hawkins ve ark.,1995; Steinberg, 2000 ve Mash and Wolfe, 2005 (akt. V. L. Austin and D. T. Sciarra, 2010:34) vurgulanması, çalışmada bulgulanan ebeveynlerin bilgi türlerinin ve düzeylerinin önemine çekilen dikkat ile oldukça örtüşmektedir.

Drews (1957), Teahan (1963) ve Nichols (1963) tarafından gerçekleştirilen üç ayrı çalışmada (akt: Erginbay, 2014), otoriter tutumun olduğu ailelerden gelen çocukların akademik başarılarının düşük olduğu, başarı göstermeleri gereken durumlar karşısında sınırlayıcı tepkiler verdikleri ve bu tutumun yaratıcılığı olumsuz yönde etkilediğinin gösterilmesi yine araştırma bulgulariyla örtüşmektedir.

Karşıt olma ve karşı gelme bozukluğu (KOKGB) gösteren çocuk ve gençlerle ilgili yapılan çalışmalarda (Maughan ve ark. 2004; Eaves ve ark. 2000; Smith ve ark.,2014 ve Chamberlin and Patterson, 1995, akt. V. L. Austin and D. T. Sciarra, 2010:59) aşırı koruyucu, ilgisiz, tutarsız ve katı disipline dayalı anne baba tutumlarının bu bozukluğun en önemli nedeni olarak gösterilmektedir. Araştırmacıların ifade ettikleri bu bulgu, araştırmada ebeveynlerin, en yüksek ortalamaya sahip tutumlarının aşırı koruyucu tutum olduğu bulgusuyla da örtüşmektedir. ( ebeveyn tutumlarının ego durumları ile ilişkisine ağırlık verilirse daha iyi olabilir. Çünkü araştırmanın odak noktası ebeveyn tutumları ile ego durumları arasındaki ilişki)

Araştırmada, öğrencilerin kendilerini algıladıkları ego durumları bakımindan, en fazla Koruyucu Ebeveyn ego durumunda (\%60), ikinci sirada ise Doğal Çocuk ego durumunda (\%23) algıladıkları, kendilerini Yetişkin ego durumunda algılayanların ise \%10 oranında olduğu görülmüştür. Transaksiyonel Analiz kuramı, kişilerin ego durumları bağlamında etkileşimlerinde, ebeveyninden Koruyucu Ebeveyn ego durumundan temas iletisi alan çocuklarda Yetişkin ego durumunun ve Uygulu Çocuk ego durumunun gelişemeyeceğini, anne babalarını daha çok model almaları nedeniyle Koruyucu Ebeveyn ego durumunun ya da Doğal Çocuk ego durumunun gelişeceğini ifade etmektedir. Dolayısıyla bu yaklaşım da araştırma bulgularımızla (ebeveynlerde aşırı koruyucu tutumun ilk sırada, öğrencilerin kendilerinde algıladıkları ego durumunun ise en fazla Koruyucu Ebeveyn ego durumunda olduğu bulguları ile) örtüşmektedir. Bu 
bulgu, Alisinanoğlu (1995)' nun, yaptığ 1 çalışmada üniversite öğrencilerinin kendilerini en çok, Koruyucu Ebeveyn ego durumunda algıladıkları bulgusuyla, Kaçar (2008)' in lise öğrencileri ile yaptığı çalışmada, koruyucu olarak algilayan öğrencilerde ise Yetişkin ego durumunun düşük düzeyde olduğu bulgusuyla örtüşmektedir.

Maccoby ve Martin ise (1983) demokratik ailelere sahip çocukların otoriter, ihmalkâr ve müsamahakâr ailelere göre daha yüksek düzeyde akademik başarıya, benlik algısına, öz-yeterlik algısına ve sosyal gelişime sahip olduğunu vurgulamıştır. Dolayısıyla araştırmada öğrencilerin kendilerinde en yüksek oranda (\%60) algıladıkları ego durumunun Koruyucu Ebeveyn ego durumu olması, yine araştırmadaki anne babaların tutumunun da en yüksek oranda koruyucu/kollayıcı tutum olduğu hatırland1ğında Maccoby ve Martin' in araştırma bulgusuyla örtüşmektedir. Araştırmanın bu bulgusu aynı zamanda Akbaba' nın (1988), üniversite öğrencilerinde, algılanan ana-baba tutumlarının benlik tasarımı üzerindeki etkilerini incelediği çalışmasında; demokratik ana-baba tutumu ile olumlu benlik tasarımı arasında pozitif bir ilişki; ilgisiz ve otoriter ana-baba tutumları ile olumlu benlik tasarımı arasında ise negatif yönde bir ilişki olduğu bulgusuyla, Güven (1993), öğrencilerle yaptığı çalışmada ana-baba tutumları ile benlik kavramı arasındaki olumlu yönde bir ilişki olduğu bulgusuyla, Gürler (2017)' in çalışmasında, demokratik anne baba tutumu ile gençlerin benlik saygısı arasında pozitif yönde anlamlı bir ilişki, otoriter ve koruyucu anne baba tutumu ile benlik saygısı arasında da negatif yönde anlamlı bir ilişki olduğu bulgusuyla örtüşmektedir.

Araştırmada, anne babaların, çocuk yetiştirmeye ilişkin tutumları ile anne babalık bilgi düzeyleri arasında negatif yönlü anlamlı bir ilişki olduğu görülmüştür. ( bu cümle tam anlaşılmıyor. Hangi tutumdan bahsediliyor?) (r=-.449; $\mathrm{p}<.01)$. Yani anne babaların, hamilelik, bebeklik, çocukluk ve ergenlik dönemlerine ilişkin bilgi düzeyleri ne kadar düşük ise sağlıksız tutumları arttıracağı söylenebilir. Yukarıda gerek anne baba bilgi düzeyi gerekse tutumlar konusundaki bulgulara dayalı açıklamalar yine bu bulgumuzla örtüşmektedir.

Araştırmada, anne babaların çocuk yetiştirmeye ilişkin tutumlarının, öğrenim durumlarına göre anlamlı farkl1lık gösterdiği $\left(\mathrm{F}_{(3-121)}=9,74 \mathrm{p}<, 01\right)$ bulunmuştur. Bu farkın da ilkokul mezunu anne babalar ile üniversite mezunu anne babaların puan yüksekliğinden kaynaklandığ1 görülmüştür. 
Yani ortaöğrenim mezunu olmanın ilkokul veya üniversite mezunu olmaya kıyasla bir farklılık yaratmadığı görülmüştür. Bu bulgu Erginbay' in (2014) yaptığı çalışmadaki, ilkokul mezunu olan anne ve babaların aşırı koruyucu puanlarının üniversite mezunu olan anne ve babalardan yüksek olduğu bulgusuyla örtüşmektedir. Benzer şekilde, Mızrakçı' nın (1994) annelerin çocuk yetiştirme tutumları üzerinde etkili olan faktörleri ele aldığı çalışmasında, annelerin eğitim düzeyi arttıkça demokratik tutumunda arttığ1 ve aynı zamanda otoriter ve koruyucu tutumun azaldığ1 bulgusuyla ve Demiriz ve Öğretir' in (2007) yaptığı çalışmadaki bulgularıyla örtüşmektedir. Dolayısıyla üniversite eğitiminin, ilköğretim ve ortaöğretime kıyasla, anne babaların çocuk yetiştirmeye ilişkin sağlıklı tutumlar ortaya koymalarında önemli olduğunu göstermektedir. Araştırmada, anne babaların, anne babalık bilgi düzeylerinin öğrenim durumuna göre farklılaşıp farklılaşmadığına ilişkin bulguda da üniversite mezunu olanların anne babalık bilgi düzeylerinin, ortaöğrenim ve ilkokul mezunlarına göre daha yüksek olduğu görülmektedir. Bu iki bulgu bilginin tutumu önemli ölçüde belirlediğini ortaya koymaktadır.

Araştırmada çocuk yetiştirme tutumları bakımından, çalışmayan anne babalar, çalışan anne babalara göre aşırı koruyucu, baskıcı-disiplinli tutum ve evlilikte çatışma alt boyutlarında daha yüksek puan almışlardır. Öğrenim düzeyi bakımından düşünüldüğünde, üniversite mezunu bireylerin, öğrenim düzeyleri ilkokul ya da ortaöğrenim olan bireylere kıyasla iş bulabilme ve çalışabilme olasılıklarının daha yüksek olacağının doğal bir durum olacağı düşünüldüğünde ve yukarıda belirtilen üniversite mezunu olan anne babaların tutumlarının diğer öğrenim durumlarına k1yasla daha sağlıklı olduğu açıklaması göz önünde bulundurulduğunda, ( Bu cümle çıkartılabilir) çalışmayan anne babaların çocuk yetiştirmede, daha çok büyüklerinde gözlemledikleri davranışlardan hareketle yani geleneksel bilgiye dayalı olarak tutumlar ortaya koyacakları büyük bir olasılıktır. Aksoy ve Kılıç' in (2009), Asya Kültürlerinde Ebeveynlik Stilleri ve Uygulamaları konusunda yaptıkları çalışmada da belirtildiği üzere, geleneksel kültürlerin ağırlıklı olduğu toplumlarda anne ve babalar anne ve babalarından gördükleri ve toplumda kabul gören tutumlar ortaya koyarlar. Bu bağlamda Türkiye, geleneksel kültürün ağırlıkta olduğu bir yapıdadır ve çocuk yetiştirmede otoriter ebeveynliğe bağlı olarak yüksek düzeyde kontrol ve baskı söz konusudur. Kağıtçıbaşı' na (1998:59) göre de 
geleneksel toplumlarda aile yapısında ve çocuk yetiştirmede normlar esastır, çocuğun bağımsızlığı yoktur, itaate yönelik ilişkisellik vardır ve kontrol ağırlıktadır.

Anne babaların çocuk yetiştirmeye ilişkin bilgi düzeylerinin, çalışmayan anne babalara kıyasla çalışan anne babalar lehinde anlamlı bir farkl1lık göstermesinin araştırmada bulgulanması da bu çerçevede değerlendirilebilir. Aynı zamanda çalışan anne babaların çalışma ortamında gerek farklı meslek grubundaki insanlarla etkileşimlerinin gerekse kendileri gibi anne baba konumundaki bireylerle etkileşimlerinin (özellikle çocuklarıyla ilgili paylaşımlarında) bu bilgi düzeyini olumlu yönde genişleteceği de bir gerçektir. Dolayısıyla çalışan anne babaların çalışmayan anne babalara k1yasla çocuk yetiştirmeye ilişkin bilgi düzeylerinin daha yüksek olması beklenen bir sonuç olarak değerlendirilebilir.

Araştırmada elde edilen, anne babaların çocuk yetiştirmeye ilişkin bilgi düzeylerinin anne baba tutumlarını anlamlı düzeyde yordadığı bulgusu aslında hem yukarıdaki bulguları açıklar niteliktedir hem de yapılan açılamalarla örtüşmektedir.

Sonuç olarak; çocuk yetiştirmede sağlıklı anne baba tutumlarını, anne babalık bilgi düzeyinin, anne babalık bilgi düzeyini de önemli ölçüde üniversite mezunu olmanın belirlediği görülmektedir.

Araştırmadan elde edilen bulgular bir arada değerlendirildiğinde, katılımcı anne babaların çocuk yetiştirmeye ilişkin hem sağlıklı tutumlara sahip olmadıkları hem de anne babalık bilgi düzeyi bakımından oldukça düşük puanlar aldıkları görülmektedir. Tutumu belirleyen en önemli unsurun da bilgi olduğu hem araştırmacılar tarafından ifade edilmekte hem de sosyal psikoloji alanındaki kuramcilar tarafından özellikle vurgulanmaktadır. Bu araştırma sonuçları da bu görüşler ile örtüşmektedir. Çünkü çalışmada anne baba tutumlarını, anne babalık bilgi düzeyinin önemli ölçüde belirlediği; anne babalık bilgi düzeyini de üniversite mezunu olmanın önemli ölçüde belirlediği görülmüştür. Bununla birlikte anne babaların anne babalık bilgi düzeyi bakımından testin alt boyutlarının hiçbirinde (hamilelik, çocukluk ve ergenlik) çok iyi düzeyde denilebilecek puanlar alamadıkları, iyi düzeyde ise sadece ergenlik dönemine ilişkin puanlar aldıkları görülmüş̧ür. Sahip oldukları bilgi kaynaklarının ise daha çok magazinsel ve geleneksel bilgi olduğu bu kaynakların da anne babalık bilgi 
düzeyleri bakımından çok yetersiz ve yetersiz düzeyi beraberinde getirdiği görülmüştür. Anne babaların bilimsel bilgiyi kaynak olarak kullanma düzeyleri ise arzu edilen düzeylerin uzağında olup vasat düzeyde bile degildir.

Bilginin tutumu belirlediği düşüncesini ve yaklaşımını destekleyen araştırma bulgularına göre anne babaların çocuk yetiştirmeye ilişkin tutumlar bakımından da en sağlıksız tutumlardan biri olan aşırı koruyucu/kollayıcı tutuma sahip oldukları görülmektedir.

Araştırma katılımcılarından biri olan öğrencilerin sonuçlarına bakıld1ğında ise; öğrencilerin kendilerini algıladıkları en fazla Koruyucu Ebeveyn ego durumunda (\%60), ikinci sırada ise Doğal Çocuk ego durumunda (\%23) algıladıkları, kendilerini Yetişkin ego durumunda algılayanların ise $\% 10$ oranında olduğu bulgulanmıştır.

Transaksiyonel Analiz kuramı, kişilerin etkileşimlerinde, ebeveyninden Koruyucu Ebeveyn ego durumundan temas iletisi almaları durumunda, ebeveynlerini model alacakları için Koruyucu Ebeveyn ego durumunun ya da Doğal Çocuk ego durumunun gelişeceğini, Yetişkin ego durumunun ise gelişmesinin pek mümkün olamayacağını ifade etmektedir. $\mathrm{Bu}$ da aslında araştırma bulgularımızla örtüşmektedir. Araştırmamızda öğrencilerin kendilerinde algıladıkları ego durumunun da en fazla Koruyucu Ebeveyn ego durumunda (\%60), ikinci olarak Doğal Çocuk ego durumunda (\%23) olduğu, Yetişkin ego durumunda kendini algılayanların ise çok düşük düzeyde (\%10) olduğu görülmektedir. Bu sonuçlar, gençlerin sağlıklı bir kişilik geliştirebilmesi ve dolayısıyla sağlıklı toplumları oluşturabilmeleri adına kaygı verici düzeydedir. Çünkü, bilimsel bilgiye dayalı olarak demokratik tutumun sergilendiği bir aile ortamında yetişmeyen çocukların, sosyal ortamlarda kendini medeni cesaret ile ortaya koyabilmesi, benlik saygısının yüksek olması, sağlıklı etkileşimler gerçekleştirebilmesi ve bilgiye dayalı düşünme ve sorgulama becerisine sahip olması beklenebilir bir durum gibi görünmemektedir. Böyle aile yapılarıyla ilintili olarak, itaate dayalı tutumların ve magazinsel bilgilerin ağırlıkta olduğu bir toplumsal yapı da öngörülemez değildir. Kağıtçıbaşı' nın (2010) kültürel farklılıkları dikkate alarak incelediği aile yapılarının çocukluktan itibaren bireylerde hangi benlik türlerini ağırlıklı olarak ortaya çıkartabileceğini ele aldığı kapsamlı çalışması bu düşüncelerle örtüşmektedir. 


\section{Öneriler}

1. Bu çalışma aynı amaçlar çerçevesinde araştırmanın yapıldığı il dışında ülkemizin başka şehirlerinde de yapılıp, bölgeler ve şehirler bakımından sonuçlar karşılaştırılabilir.

2. Sağlıklı anne baba tutumları ve anne babalık bilgi düzeyinin artırılması amaciyla devlet kurumlarının yanısıra özel kurumlarda, belli sayıda çalışanı olan, işletmelerde, hizmet içi eğitimler kapsamında anne babalık seminerleri düzenlenmesi desteklenebilir, teşvik edilebilir.

3. Kitle iletişim araçları ana-babalık bilgisini ve saglıklı ana-baba tutumları bilgilerini uygun saatlerdeki uygun programlarda ele alabilir.

4. Ana-baba tutum ölçeklerinin kültürel farklılıklar gösterebilir olması kadar annelik babalık bilgisiyle ilgili şu anda net olmayan bazı öğeler de kültürel farklılıktan etkilenebilir. Bu nedenle kültürümüze uygun tanımların kullanılacağ ve kültürümüze uygun bilgilerin yer alacağ ana-babalık bilgisi üzerine çalışmalar genissletilebilir ve bu bilgilerin daha saglıklı ölçülebileceği araçlar geliştirilebilir.

5. Öğrencilerin kendilerinde algıladıkları ego durumlarının gelişmesinde rol model aldıkları kişilerin etkili olduğu görülmektedir. Öğrencilerin model almış oldukları ebeveynlerinin hatta öğretmen ve öğrencilerin Yetişkin ego durumuna uygun davranış sergilemeleri için TA eğitimleri verilebilir.

6. Bu çalışma geliştirilerek anne babalara da TA çerçevesinde ego durumları analizi yapılıp anne baba tutumlarıyla birlikte incelenebilir. Öğrencilerin kendi ego durumlarını ve ebeveynlerinin ego durumunu tanıması iletişim kurarken doğru ego durumlarından birbirlerine yaklaşmalarını ve böylece ilişkinin daha saglıklı bir düzeyde yürütülmesini sağlayabilir. 
EXTENDED ABSTRACT

\title{
Relationship Between Ego States in Teenagers in 13- 18 Age Group and Consciousness Levels of Parents with Parents' Attitude
}

$*$

\author{
Seden Durmuş Çalışkan - Halis Özerk \\ Arel University
}

Family is described by Turkish Language Association (TLA) as "Family is the smallest community that consists of relationships among wife, husband, children, and siblings based on marriage and kindredship" (TLA, 2017). For Baumrind (1971) and Rohner, Khaleque and Cournnoyer (2007); family structures and parents' attitudes relating to child-rearing can determine whether personal development and behaviors of children will be positive or negative in terms of healthiness.

Concerning Horney, the condition for a child to develop a healthy behavior and personality is the presence of an environment with unconditional love, appropriate support, and a natural understanding. A child can develop himself by healthfully passing developmental periods in such a family environment (Geçtan, 1992, p.167).

In this sense, it is accepted that basic behavioral patterns and personal characteristics of individuals are predominantly formed in the family environment (Özerk, 2006, p.4).

Özerk (2006, p.116-117) proved that parents' attitudes in the childrearing process are based on magazinish knowledge at most and scientific knowledge at least. again, for related research results, parental knowledge level is under (low level) the required ratio without noticing educational background, socioeconomic level, and gender.

Studies in developmental psychology go long way back as well as there are various explanations toward social and personal development of child regarding parents' attitudes. The common fact of them is that parents' attitudes are a vital factor that can affect the character and human relations of the child (Senemoğlu, 2009, p.11). 
Accordingly, being endeavored children to direct by own discipline methods of parents may cause children to be persons who are compatible or noncompatible in social life. Ego states of adolescents that were analyzed in the research, for Berne, start to be formed based on interaction styles in a family environment as from the birth; forming is completed in 12 ages (Akkoyun, 1995, p.10). Literature surveys show that there is no study (national and international publications) that analyzed the relationship of both parents' attitudes and parental knowledge with ego states. So, this study was planned and performed to fill this gap of literature.

In this study, it is aimed to reveal the relationship of ego states of teenagers in the 13-18 age group with parentage consciousness levels of parents and their attitudes relating to child rearing. In addition, this paper also scrutinizes this relationship in terms of several demographical variables such as age, gender, educational background, and socio-economic level.

The population consisted of teenagers in the 13-18 age group who study in secondary education in Akçakoca, Cumayeri and Çilimli districts of Düzce province; families of these teenagers were also included in the population. Sample of the study composed of 260 persons whose 130 were parents and other 130 were the teenagers in the related age group.

The sampling method is the clustering irrational random sampling; it is in the form of relational screening model.

Ego States Scale (ESS) within the scope of Transactional Analysis Theory was applied 130 teenagers in 13-18 age group by asking them for checking the boxes which summarize their characteristics. As data collection tools, 130 parents in the survey was applied Parentage Information Test and Parental Attitude Research (PARI) whose validity and reliability are approved. Moreover, the Demographic Information Form that was developed by the same investigator was filled by participants. The significance level of all the data was tested at $\mathrm{p}<0.05$ level.

There is found a negative significant relationship between parents' attitudes relating to child rearing and parentage consciousness levels. 
There is also seen a significant difference between parentage information level of parents between their educational level, working status and number of children. In addition to all these, for research results, parents significantly predict PARI scores.

For many research results (Baldwin,1948; cited by. Ş. Erginbay; 2014; Drews,1957; Teahan,1963, Nichols 1963; Akbaba, 1988; Eastman, 1988; Diaz, 1989; Güney, 1989; Berber, 1990; Aksaray, 1992; Bostan, 1993; Akbağ, 1994; Yücedağ, 1994; Yeşilyaprak, 1998; Tuzgöl, 2000; Sipahioğlu, 2002; Peksaygilı and Güre, 2008; Kula, 2008; Özdemir, 2009; Avc1, 2010; Vidinlioğlu, 2010; Yaşa, 2012) relating to the relationship of parents' attitudes and behavioral problems in youth, nurturing and domineering attitude is unhealthy attitudes; this finding jibes with this research finding.

At the same time, the most important and known factor in behavioral disorders is psychosocial factors; parents' attitudes have a determining role (Burke et al., 2002; Capaldi and Patterson, 1996; Hawkins et al.,1995; Steinberg, 2000 and Mash and Wolfe, 2005 (cited by. V. L. Austin and D. T. Sciarra, 2010, p.34). This finding jibes with our study findings in terms of the attention that is attracted to types and levels of parental knowledge.

It is seen in a study that studies perceive themselves in Nurturing Parent ego state at most (60\%); Natural Child ego state ranks number two (23\%). Students who perceive themselves in Adult ego state is at $10 \%$. Transactional Analysis Theory points out that the Adult ego state and Adaptive child ego state cannot develop in children who receive Nurturing Parent ego state contact message from parents. Since children take their parents as a model, Nurturing Parent ego state and Natural Child ego state will develop. Thus, this approach jibes with our research findings (excessive nurturing attitude is at the first place; the selfperceived ego state of children is in Nurturing Parent ego state). This finding jibes with Alisinanoğlu's (1995) study which found that university students perceive themselves in Nurturing Parent ego state at most. Again, this finding also jibes with Kaçar's (2008) study finding which emphasized that Adult ego state is at a low level in students who perceive themselves in Nurturing Parent ego state. 


\section{Kaynakça / References}

Akbaba, S. (1988). Ana-baba tutumlarının bazı kișilik özellikleri üzerine etkisi. Yayınlanmamıs, Yüksek Lisans Tezi, Gazi Üniversitesi Sosyal Bilimler Enstitüsü, Ankara.

Akbağ, M. (1994). Liseli ergenlerin ana baba tutumların algılamalar ile uyum düzeyleri arasındaki ilişkinin incelenmesi. Yayımlanmamış yüksek lisans tezi, Marmara Üniversitesi SBE, İstanbul.

Akbağ, M. (2000). Stresle başa çıkma tarzlarının üniversite ögrencilerinde olumsuz otomatik düşünceler, transaksiyonel analiz ego durumları ve bazı degisskenler açısından incelenmesi. Doktora Tezi, Marmara Üniversitesi Egitim Bilimleri Enstitüsü, Istanbul.

Akkoyun, F. (1995). Transaksiyonel analiz. Ankara: 72 TDFO.

Akkoyun, F. (2011). Transaksiyonel analiz. Ankara: Nobel Yayınevi.

Aktaş, S. (2011). 9. sınıfta anne baba tutumları ve benlik saygısı arasındaki ilişkinin bazı değişkenler açısından incelenmesi. Yayımlanmamış Yüksek Lisans Tezi. Selçuk Üniversitesi Eğitim Bilimleri Enstitüsü, Konya.

Alisinanoğlu, F. (1995). Üniversite öğrencilerinin ben (EGO) durumları ile anababa tutumların algılamaların etkileyen bazı değişkenlerin incelenmesi. Doktora Tezi, Ankara Üniversitesi Fen Bilimleri Enstitüsü, Ankara.

Aşıll, G. (2001). Üniversiteli ögrencilerin cinsiyet rolleri ve ego (Ben) durumları arasindaki iliş,ki. Yayımlanmamış Yüksek Lisans Tezi, Selçuk Üniversitesi Sosyal Bilimler Enstitüsü, Konya.

Austin, V. L ve Sciarra, D. T., (2010). Child and adolescents with emotional and behavioral disorders, (Çev. Ed. M. Özekes, 2012. Çocuk ve Ergenlerde Duygusal ve Davranışsal Bozukluklar. Ankara: Nobel Akademik Yayınları.

Aydoğmuş, K. ve diğerleri, (2001). Ana- baba okulu. H. Yavuzer (Ed.) İstanbul: Remzi Kitabevi.

Baumrind, D. (1971). Harmonious parents and their preschool children. Developmental Psychology, 4, 99-102.

Baumrind, D. (1971). An exploratory study of socialisation effecet on black children: Some Black-White Comparisions. Child Development, 43, 261267.

Berber, Ş. (1990). Sosyo-ekonomik faktörlerin ve ana baba tutumlarmın okul başarına etkisi. Yayımlanmamış Yüksek Lisans Tezi, Gazi Üniversitesi Sosyal Bilimler Enstitüsü, Ankara 
Berne, E. (1961a). Transactional analysis in psychotherapy. The classic handbook to its principles. New York: Grove Press.

Berne, E.(1961b). Transactional analysis in psychotherapy: A systematic individual and social psychiatry. Pickle Partner Publishing.

Bostan, S. (1993). 14-16 yaş ergenlerin uyum düzeylerinin ve ana baba tutumlarının incelenmesi. Yayımlanmamış Yüksek Lisans Tezi. Ankara Üniversitesi Fen Bilimleri Enstitüsü, Ankara.

Bozanoğlu, İ. ve H. Özerk. (2017). The relationship of the compatibility level between self-perceived ego states of the students of faculty of health sciences and the professional ego states thought by the academicians with the academic motivation levels. Journal of Strategic Research in Social Science (JoSReSS), 3(4), 216-218.

Burke, J. D., Loeber, R. ve Birmaher, B. (2002). Oppositional defiant disorder and conduct disorder: A review of the past 10 years, part.II, Journal of American Child and Adolescent Psychiatry, 41, 1275-1293.

Capaldi, D. M. and Paterson, G.R. (1996). Can violent offenders be distinfuished from frequent offerders? Prediction from childhood to adolescence. Journal of Research in Crime and Delinquency, 33, 206-231.

Casler, M. E. (1995). Motivational factors for adoptive parenthood. Unpublished Dissertation. USA.: University of Pittsburgh.

Cüceloglu, D. (1992). İnsan ve davranıșı, Psikolojinin temel kuramları. İstanbul: Remzi Kitapevi.

Cüceloglu, D. (1993). Iyi düşün dogřu karar ver. İstanbul: Sistem Yayıncılık.

Çağdas, A.(2002). Anne-baba-çocuk iletişimi. Ankara: Nobel Yayınevi.

Çağdaş, A. ve Seçer Ş.(2002). Çocuk ve ergende sosyal ve ahlak gelişimi. Ankara: Nobel Yayınevi. 60-65

Dabak N. (2007). Illköğretim birinci kademede davranış, sorunları olan çocukların anne - baba tutumları. Yayımlanmamış, Yüksek Lisans Tezi, Kocatepe Üniversitesi Sosyal Bilimler Enstitüsü, Afyonkarahisar.

Demiriz, S. ve A.D. Ögretir. (2007). Alt ve üst sosyo-ekonomik düzeydeki 10 yaş çocuklarının anne tutumlarının incelenmesi. Kastamonu Egĭtim Dergisi, 15(1), 105- 122.

Eaves, L. Rutter, M. Silberg, J. L., Shillady, L., Meas, H. ve Pickles, A. (2000). Genetic and environmental causes of covariation in interview assesments of disruptive behavior in child and adolescent twins. Behavior Genetics, 30 (4), 321-334. 
Erginbay, Ş. (2014). Ortaokul 5. ve 8. sinıflarda algılanan anne baba tutumları ve ailelerin çocuk yetiştirme stillerinin akademik başarıya etkisi. Yayımlanmamış Yüksek Lisans Tezi. Fatih Üniversitesi Sosyal Bilimler Enstitüsü, İstanbul.

Ertuğrul, H. (2005). Ailede ve okulda çocuk egĭtimi. İstanbul: Nesil Yayıncılık.

Eyicil, T. ve Özerk, H. (2016). The relationship performances of footballers and concordance (compatibility) level of their ego states and pasitions in their team. Journal of Current Researches on Social Sciences, 6(1), 117-134.

Geçtan, E., (1992), Psikodinamik psikiyatri ve normaldışı davranışlar, 8. Baskı, İstanbul: Remzi Kitabevi.

Gökçedağ, S. (2001). Lise öğrencilerinin okul başarısı ve kaygı düzeyi üzerinde anne- baba tutumlarının etkilerinin belirlenip karşılaştırılması. Yayınlanmamış Yüksek Lisans Tezi, Dokuz Eylül Üniversitesi Eğitim Bilimleri Enstitüsü, İzmir.

Gullo, F. D. (1988). A comparative study of adolescent and older mothers' knowledge of infant abilities. Child Study Journal, 18(3), 223-231

Gümüş, İ., M. Kurt., D. Ermurat., ve E. Feyetörbay. (2011). Anne-baba tutumu ve okul başarısına etkisi. Ekev Akademi Dergisi, 47, 425-437.

Güney, M. (1989). Üniversite öğrencilerinde aile yapıları ve yetşitirmede önem verilen özellikler. Journal of Ankara Medical School, 11(2), 229 246.

Gürler, A. (2017). Ergenlerde anne baba tutumları ile benlik saygısı arasındaki ilişkinin incelenmesi. Yayımlanmamış Yüksek Lisans Tezi. İstanbul Ticaret Üniversitesi Sosyal Bilimler Enstitüsü, İstanbul.

Güven, A. (1993). Farklı öğretim programı izleyen öğrencilerde algılanan ana baba ve ögrretmen tutumlarının benlik kavramına etkisi. Yayımlanmamış Doktora Tezi, Dokuz Eylül Üniversitesi SBE, İzmir.

Harris, T. (2013). BENOK'im SENOK'sin. M.Şahin (çev.). Istanbul: Okuyan Us (orijinal baskı tarihi 1967).

Hart, L. (1987). The winning family increasing self esteem in your children and yourself. New York: Dood \& Mead Company.

Hawkins, J. D., Arthur, M. W, ve Catalano, R. F. (1995). Preventing substance abuse. In M. Tonry and D.P. Farrington (Eds.), Bulding a safer society: Strategic Approaches to Crime Prevention: 19, 343-427.

James, M., ve Jongeward, D. (1993). Kazanmak için dogărız. T. Şenruh (çev.) Istanbul: Ink1lap Kitabevi. 
Kaçar, B. (2008). Lise öğrencilerinin karar stratejileri ve transaksiyonel analiz ego (ben) durumlarının bazı değişkenler açısından incelenmesi. Yüksek Lisans Tezi. Marmara Üniversitesi Eğitim Bilimleri Enstitüsü, İstanbul.

Kağıtçıbaşı, Ç. (2010). Benlik, aile ve insan gelişimi: Kültürel psikoloji. İstanbul: Koç Üniversitesi Yayınları.

Kulaksızoğlu, A. (1989). Ergen - aile çatışmaları ile annenin tutumları arasındaki 1lişki ve ergenin problemleri. Atatürk Ĕ̆itim Fakültesi Ĕ̆itim Bilimleri Dergisi, 1, 71-78.

Kulaksızoğlu, A. (2011). Ergenlik psikolojisi. 13. Baskı. İstanbul: Remzi Kitapevi.

Kuzgun, Y. (1972). Anne-baba tutumlarının bireyin kendini gerçekleştirme düzeyine etkisi. Yayımlanmamış Doktora Tezi. Hacettepe Üniversitesi, Ankara.

Kuzgun, Y. (2000). Rehberlik ve psikolojik danışma. 6. Baskı. Ankara: ÖSYM Yayinları.

Lally, J. R., Lerner, C. ve Hurvitz, E. L. (2001). National survey reveals gaps in the public's and parents' knowledge about early childhood development. Young Children, 56 (2), 49-53.

Le Compte G, Le Compte A, Özer S ve ark. (1978) Üç sosyoekonomik düzeyde Ankara'lı annelerin çocuk yetiştirme tutumları: Bir ölçek uyarlaması. Türk Psikoloji Dergisi, 1, 5-8

Maccoby, E.E. ve J.A. Martin. (1983). Socialization in The Context Of The Family: Parent-Child Interaction. P. H. Mussen ve E. M.Hetherington (Ed.). Handbook of child psychology: Vol. 4: Socialization, personality and social development. New York: Wiley.

Mansager, E. ve R. Volk. (2004). Parents' prism: Three dimensions of effective parenting. Journal of Individual Psychology, 60 (3), 227-293.

Mızrakçı,Ş. (1994). Annelerin çocuk yetiştirme tutumlarına etki eden faktörler: demografik özellikleri, kendi yetiştiriliş tarzları, çocuk gelişimine ilişkin bilgi düzeleri ve çocuğun mizacına ilişkin algıları. Yüksek Lisans Tezi, Ege Üniversitesi, Sosyal Bilimler Enstitüsü, İzmir.

Nelson - Jones. R. (1982). Danışma psikolojisi kuramları. Akkoyun, F. (çev.). Ankara: 72 TDFO. Ltd. Şti.

Öner, N. (1997). Türkiye'de kullanılan psikolojik testler: Bir başvuru kaynağı. (3. Baskı). İstanbul: Boğaziçi Üniversitesi Yayınları. 
Özdemir, Y. (2009). Ergenlik döneminde benlik kurgusu gelişiminin ana babanın çocuk yetiştirme stilleri açısından incelenmesi. Yayımlanmamış Doktora Tezi, Ankara Üniversitesi, Eğitim Bilimleri Enstitüsü, Ankara.

Özerk H., Ada, S. ve Özerk, H. (2018). Öğretmenlerin ve okul yöneticilerinin birbirlerinde algıladıkları ve bekledikleri ego durumlarını ilişkisi. Elektronik Sosyal Bilimler Dergisi, 17(66), 779-800.

Özerk, H. (2006). Anababaların çocuk yetiştirmeye ilişkin tutumlarının, bilgi düzeylerinin ve 11-18 yaş grubu öğrencilerin kendilerini değgerlendirmelerinin incelenmesi. Doktora Tezi. Ankara Üniversitesi Eğitim Bilimleri Enstitüsü, Ankara.

Özerk, H. ve Ç. A. Mercanlığlu. (2017). The relation of compability level between self- perceived ego states of the students of faculty of health sciences and the professional ego states thought with their hope/hopelessness levels for the future. Journal of Current Researches on Social Sciences (JoCReSS), 3(4), 126-127.

Roberts, D. L. (1975). Treatment of cultural scripts. Volume of Selected Articles From the Transactional Analysis Journal. San Francisco: The International Transactional Analysis Association Inc. 183 - 189.

Rohner, R., Khaleque, A., ve Cournnoyer, D. (2007). Parental acceptance - rejection theory, methods, evidence and implications" file:// Documents and settings Parental acceptance. htm 22.08.22.

Senemoğlu, N. (2009). Geliş̧im, ögřenme ve ögřetim kuramdan uygulamaya. Ankara: Pegem Akademi.

Sertelin, Ç. (2003). Ebeveyn tutumlarının sosyo-kültürel yapı ve aile fonksiyonları ile ilişkisi. Yayınlanmamış Yüksek Lisans Tezi, İstanbul Üniversitesi Sosyal Bilimler Enstitüsü, İstanbul.

Solomon, C. (2003). Transactional analysis theory: Basic. Transactional Analysis Journal, 33, 15-22.

Stewart I., ve Joines V. (2012) TA Today: A new introduction to transactional analysis. (Çev. Ed. F. Akkoyun (2017). Günümüzde TA, 1. Baskı. Ankara: Eksi Kitaplar.

Sümer, N. ve D. Güngör. (1999). Çocuk yetiştirme stillerinin bağlanma stilleri, benlik değerlendirmeleri ve yakın ilişkiler üzerindeki etkisi. Türk Psikoloji Dergisi, 14(44), 35-58.

Türk Dil Kurumu. (2017). Büyük Türkçe sözlük. http://tdk.gov.tr Erişim tarihi: 18 Haziran 2017. 
Ünlü, H. (2002) Ögrenci, anne ve babalar için eğitim rehberi. Ankara: Șahika Yayinlar1.

Yaşa, Z. (2012). Üniversite öğrencilerinde ana baba tutumlarının suçluluk ve utanç duyguları üzerine etkisi. Yayımlanmamış Doktora Tezi, Celal Bayar Üniversitesi Tip Fakültesi Psikiyatri Ana Bilim Dalı, Manisa.

Yavuzer, H. (1998). Çocuk psikolojisi. 15. Bask1. İstanbul: Remzi Kitabevi.

Yavuzer, H., (1982). Çocuk ve suç. İstanbul: Remzi Kitabevi.

Yılmaz, A. (2000). Eşler arasındaki uyum ve çocuğun algiladığı anne- baba tutumu ile çocukların, ergenlerin, gençlerin akademik başarıları ve benlik algıları arasındaki iliş̧iler. Yayınlanmamış, Doktora Tezi, Hacettepe Üniversitesi, Sosyal Bilimler Enstitüsü, Ankara.

Yörükoğlu, A. (1993). Çocuk ruh sağhı̆̆ı. 18. Baskı. İstanbul: Özgür Yayınları.

Yücel, Y. (2013). Ortaokul öğrencilerinin algzladıkları anne baba tutumlarının, benlik saygısı ve öğrenilmiş çaresizlik ile ilişkisi. Yüksek Lisans Tezi. T.C. Arel Üniversitesi Sosyal Bilimler Enstitüsü, İstanbul.

\section{Kaynakça Bilgisi / Citation Information}

Durmuş-Çalışkan, S. ve Özerk, H. (2019). 13-18 yaş grubu ergenlerdeki ego durumları ile anne babalarının bilgi düzeyleri ve anne baba tutumlarının ilişkisi. OPUS-Uluslararası Toplum Araştırmaları Dergisi, 13(19), 884-921. DOI: 10.26466/opus 594514. 